\title{
Measuring state-level infant and toddler well-being in the United States: Gaps in data lead to gaps in understanding
}

\author{
Renee Ryberg $^{1}$ (D) Lisa Wiggins ${ }^{2}$ (D) Kristin A. Moore $^{3} \cdot$ Sarah Daily $^{3}$. \\ Gabriel Piña ${ }^{3}$ (D) Ami Klin ${ }^{4}$
}

Accepted: 12 December 2021 /Published online: 2 March 2022

(c) The Author(s) 2022

\begin{abstract}
Children who are nurtured, protected, and supported in the first years of life tend to have better individual outcomes and are more likely to grow to become healthy, productive adults. Child well-being varies across states, yet the field lacks a comprehensive review of infant and toddler indicators measured at the state-level. This paper reviews indicators of well-being from the prenatal period to three years that meet certain a priori criteria. Most of the child-level indicators identified were in the physical health domain; relatively fewer indicators were found in the early cognition and language or social-emotionalbehavioral domains. While some states are making progress toward developing integrated early childhood data systems, more work is needed to provide robust data on infant and toddler development. These results highlight the need to develop a broader range of indicators of infant and toddler well-being and improve measurement sources to better inform policies and programs advancing population health.
\end{abstract}

Keywords Infant/toddler $\cdot$ Early childhood well-being $\cdot$ Indicators

Equitable, prosperous, and sustainable societies are born from healthy children (Shonkoff \& Phillips, 2000). Children who are nurtured, protected, and supported in the first years of life tend to have better individual outcomes and are more likely

The findings and conclusions in this report are those of the authors and do not necessarily represent the official views of the CDC.

Renee Ryberg

rryberg@childtrends.org

1 Child Trends, Chapel Hill, NC, USA

2 Centers for Disease Control and Prevention, Atlanta, GA, USA

3 Child Trends, Bethesda, MD, USA

4 Marcus Autism Center, Emory University School of Medicine and Children's Healthcare of Atlanta, Atlanta, GA, USA 
to grow to become more productive adults (Bailey et al., 2020; Center on the Developing Child, 2007; Center on the Developing Child, 2010; Shonkoff and Phillips, 2000). Yet not all children have an equitable start in life. Racial and ethnic disparities in well-being emerge even before birth (Wilkinson et al., 2021), and inequities by additional sociodemographic factors (e.g., family income, home language, and maternal education) across domains of development become evident at nine months and grow larger as infants become toddlers (Halle et al., 2009). These early years are crucial to healthy development due to the rapid changes in brain connectivity and skill acquisition that occur during this time (Masten \& Cicchetti, 2010; Shonkoff \& Phillips, 2000). Accordingly, the first three years have become a central focus of policies and programs designed to improve overall child well-being (Prenatal-to-3 Policy Impact Center, 2021).

Child well-being is globally defined as "the multi-dimensional nature of health that is enhanced when physical, cognitive, and social-emotional-spiritual development is nurtured in developmentally appropriate ways" (The Alliance for Child Protection in Humanitarian Action, 2021, p. 11). The well-being of children from the prenatal period to three years, henceforth referred to as "infant and toddler wellbeing," varies across states (Keating et al., 2020). For instance, some states have higher infant mortality rates than others (CDC, 2021), which may lead to variations in policy and practice interventions. It is therefore important to develop indicators available for all states and the District of Columbia (DC) to help monitor how well communities fare compared to others on an outcome of interest at a single point in time (Szilagyi \& Schor, 1998; Moore \& Brown, 2003). Additionally, state-level indicators can be used to monitor trends in infant and toddler outcomes and enable researchers to assess associations between individual factors, policies and programs, and overall health and development.

Although associations with indicators cannot establish causality, they can inform whether policy interventions, such as expanding economic supports for disadvantaged families, are associated with better outcomes. Building on this understanding, indicators can help states set goals or targets for policies and programs, invest in advantageous policies and programs, and respond to the needs of families, educators, policymakers, and public health officials. Moreover, indicators can help states identify sub-populations of children who may be at risk for adverse outcomes, such as children and families who have faced racial discrimination and children of families with lower income (Keating et al., 2020; Wilkinson et al., 2021).

Efforts to identify indicators of child well-being have been undertaken in the United States since the 1970s (Lippman, 2007; Moore, 2020). Most indicator reports have tended to focus on a small set of negatively oriented indicators for preschool and school-aged children measured by well-established data collection systems (Moore, 2020; Moore et al., 2004). A major gap in the literature is a comprehensive review of both positive and negative indicators of infant and toddler well-being available for every state and DC that can inform policies and programs. The goal of this paper is, therefore, to review indicators of infant and toddler well-being that are publicly available, measured across states, representative of state populations, and measured over time. This review builds upon extant work by providing a conceptual framework, identifying a priori inclusion criteria for indicators and measurement 
sources, identifying gaps in measurement, and informing future efforts related to childhood indicator research.

\section{Theoretical framework}

Given an understanding that child development is a multi-faceted process continually influenced by internal and external forces that work together to shape the individual child, a social-ecological framework guides this review (Bronfenbrenner, 1979, 1992, 2007). The authors adapted the well-known social-ecological model to apply specifically to the infant and toddler context (see Fig. 1): Indicators at the individual level are influenced by indicators at the family, community, and societal levels. This paper focuses on indicators of infant and toddler well-being at the child level (the innermost circle) and the most proximal contextual factors that influence the child's development and well-being (the family and caregivers circle). We did not focus on the neighborhood or the more distant contexts of development to limit the scope of the review to those most proximal to child development. We specifically focused on indicators of nurturing care identified by the World Health Organization, United Nations Children's Fund, World Bank Group (2018): good health, adequate nutrition, responsive caregiving, security and safety, and opportunities for early learning. Within the span of child development, these indicators of infant and toddler well-being can be thought of as related to current child well-being. Infant and toddler well-being indicators are also predictive of well-being during later parts of the life course, or "well-becoming" as indicated by the arrow at the bottom of the figure (Ben-Arieh et al., 2001).

\section{Methods}

We took a four-step approach to review the state of measurement of infant and toddler well-being in the United States. We (1) developed criteria for identifying relevant indicators, (2) compiled a list of potential indicators using those criteria, (3) reviewed measurement sources for each potential indicator, and (4) solicited expert input on the list of indicators and their measurement sources. Each of these steps is described in more detail below.

\subsection{Criteria for identifying potential indicators}

Before identifying indicators of infant and toddler well-being, we first developed criteria for indicators to include in the review. Substantively, we were interested in measures of infant and toddler well-being that are relevant for children prenatally to age three, have a demonstrated connection to long-term outcomes, and focus on the child or their family or caregivers. We did not include more distal contextual indicators, such as those about the neighborhood or policy environments. 


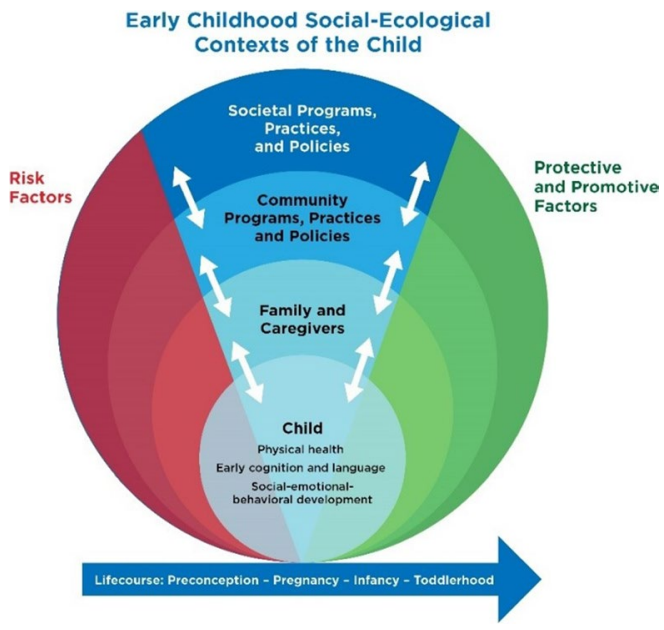

Note: This model was adapted from Bronfenbrenner (1979)'s social-ecological model for this paper.

Fig. 1 Framework for the identification of infant and toddler well-being indicators

\subsection{List of potential indicators}

We next compiled a list of potential indicators of infant and toddler well-being that met the substantive criteria outlined above. Specifically, we conducted a focused review of academic literature in early child development as well as existing indicator tracking work from non-profit research organizations that have published datadriven advocacy or policy work, including the Zero To Three State of Babies Yearbook (Keating et al., 2020), the University of Texas at Austin Prenatal-to-3 Policy Impact Center's Roadmap (Prenatal-to-3 Policy Impact Center, 2020), the National Center for Children in Poverty's Improving the Odds for Young Children State Early Childhood Profiles (National Center for Children in Poverty, 2018), and the Child Trends DataBank (Child Trends, 2020). The compiled list of all potential indicators based on this review is available in Appendix A.

\subsection{Measurement sources for potential indicators}

Then, we looked for sources of measurement for these potential indicators. Specifically, we looked for sources that are publicly available, comparable for all 50 states and DC, representative of state populations, and measured at regular time intervals (e.g., annually). The sources that met these criteria and were included in this review are outlined in Table 1. 


\subsection{Expert input on indicators and measurement sources}

We convened two meetings of experts in August 2020 to solicit feedback on our process and preliminary findings. Experts were identified by the authors and invited to attend one of two meetings. The first group was comprised of experts on early childhood administrative data, and the second group was comprised of experts on early childhood development. ${ }^{1}$ Both groups provided input on relevant child and family/caregiver indicators as well as data quality and coverage. The experts agreed that our review had not missed any substantive indicators or major data sources, and their feedback is incorporated throughout this manuscript.

\section{Results}

Following the framework outlined in Fig. 1, we present the identified indicators of infant and toddler well-being that have measurement sources meeting our criteria categorized into three broad domains: physical health, early cognition and language, and social-emotional-behavioral development. Within each domain, we describe two types of indicators: those at the child-level and those at the family/caregiver level. Some of these indicators apply to multiple domains and have multiple measurement sources. See Appendices B-D for a complete listing of all indicators by developmental domain. This information is current as of Spring 2021.

\subsection{Early physical health indicators}

Many child health indicators are measured at birth, including birthweight (used to identify births with low birthweight); gestational age (used to identify preterm births); some health conditions of the newborn; some treatment received at birth (e.g., neonatal intensive care unit [NICU] admission, antibiotics); and infant mortality (Table 2). Data on these indicators are collected from birth and death certificates and are available through the CDC's National Vital Statistics System (NVSS). From birth to 3 years, child indicators can be constructed using data on immunizations, physical health, oral health, sleep habits, and special health care needs using data from CDC's National Immunization Survey (NIS) and the National Survey of Children's Health (NSCH) (see Appendix B).

Family/caregiver indicators of infant and toddler physical health include whether the child is covered by health insurance (CPS), the adequacy and consistency of that

\footnotetext{
${ }^{1}$ Experts included Leanne Barrett of Rhode Island Kid Count, Lindsey Bullinger of Georgia Tech, Tamara Halle of Child Trends, Erin Hardy of Data Diversity Kids and the Institute for Child Youth and Family Policy at Brandeis University, Amy Madigan at the Office of Planning, Research and Evaluation's Division of Child and Family Development, David Murphey (independent consultant), William O'Hare (independent consultant), Michelle Osterman of the Centers for Disease Control and Prevention's National Center for Health Statistics, Emily Putnam-Hornstein of the University of North Carolina at Chapel Hill, Holly Sexton of the University of Texas at Austin, and Jennifer Verbrugge of the Minnesota Department of Education.
} 


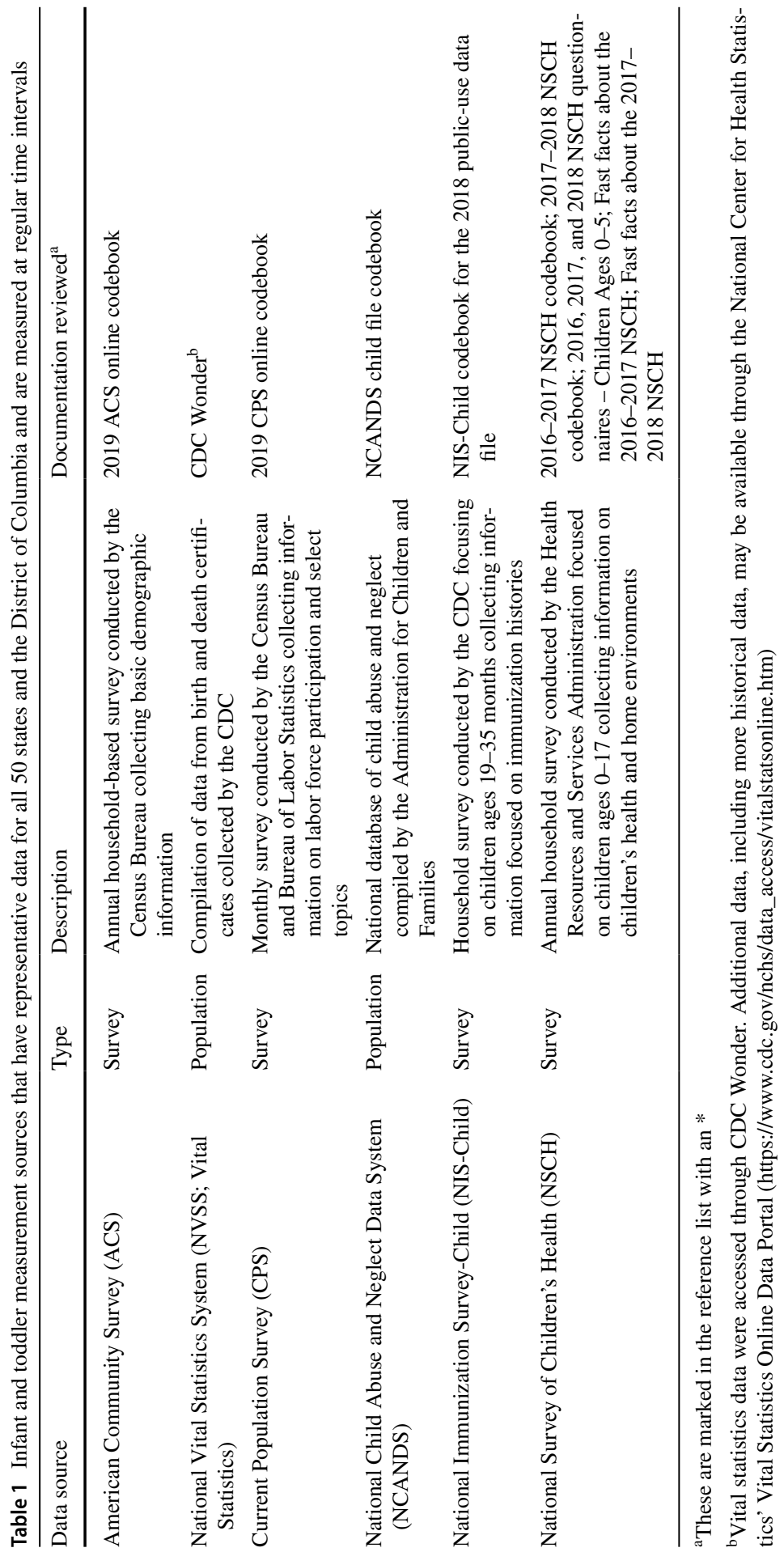


Table 2 Select infant and toddler physical health indicators available at the child or family/caregiver levels

Indicator

Primary source

Child indicators

Low birthweight: Percent of babies with birthweight less than 5.5 pounds

NVSS

Preterm birth: Percent of babies born before 37 completed weeks of gestation

NVSS

Infant mortality rate: Deaths under 1 year of age per 1000 live births

NVSS

Abnormal conditions of newborn: Percent of babies who experienced certain conditions at birth (assisted ventilation, NICU admission, surfactant replacement therapy, antibiotics for suspected neonatal sepsis seizures)

Congenital abnormalities: Percent of babies who experienced congenital abnormalities (Anencephaly, Cleft Palate Alone, Cleft Lip with or without Cleft Palate, Cyanotic Congenital Heart Disease, Congenital Diaphragmatic Hernia, Omphalocele, Gastroschisis, Hypospadias, Meningocele/ Spina Bifida, Limb Reduction Defect, Down Syndrome, Suspected Chromosomal Disorder, Congenital Anomalies)

Immunizations: Percent of toddlers ages 19-35 months who are up to date on recommended immunizations

Special health care needs: Percent of infants and toddlers who have special health care needs

Family/caregiver indicators

Health insurance: Percent of infants and toddlers with any health insurance

NVSS

NVSS

Adequacy of health insurance: Percent of infants and toddlers with health insurance that $\mathrm{NSCH}$ adequately covers their needs for the entire past 12 months

Prenatal care: Percent of infants and toddlers whose mothers received timely prenatal care

Preventive medical visit: Percent of infants and toddlers who saw a health care professional when they were not sick in the past 12 months

Medical home: Percent of infants and toddlers who receive coordinated, ongoing comprehensive care within a medical home

Maternal health: Percent of babies whose mothers experienced specific health conditions during pregnancy (eclampsia, gestational diabetes, gestational hypertension, infections)

Maternal mental health: Percent of infants and toddlers whose mothers have less than optimal mental health

Breastfeeding initiation: Percent of infants and toddlers who were ever breastfed

Breastfeeding duration: Percent of infants and toddlers who were breastfed more than 6 months

Food security: Percent of infants and toddlers living in food secure households

NVSS

$\mathrm{NSCH}$

$\mathrm{NSCH}$

NVSS

$\mathrm{NSCH}$

NIS

NIS

CPS Food

Security

Supplement

Maltreatment: Maltreatment rate per 1000 infants and toddlers

NCANDS

This is a select set of physical health indicators. See Appendix B for a full set of indicators and details about their measurement properties

insurance (NSCH), the food security of their household (CPS), whether the child received preventative care visits (NSCH), and whether the child has access to a medical home (NSCH). Information is also available on a series of indicators related to the mother's health, including receipt of timely prenatal care and maternal health 
Table 3 Select infant and toddler cognition and language indicators available at the child or family/caregiver levels

Child indicators

Cognitive/language development: NSCH asks a series of items for children ages 1-5

$\mathrm{NSCH}$ about their ability to speak, form sentences, and ask questions, and follow directions.

Developmental Delays: Percent of infants and toddlers whose parents have been told by NSCH a health care provider that they have a developmental delay

Family/caregiver indicators

Developmental Surveillance: Percent of infants and toddlers whose parents were asked by a health care provider about the child's learning, development, or behavior

Developmental screening: Percent of infants and toddlers whose parents filled out a developmental screener from a health care provider in the past year

Reading to children: Percent of infants and toddlers who are read to every day

Singing and telling stories: Percent of infants and toddlers who are told stories or sung songs to every day

This is a select set of the most well-measured early cognition and learning indicators. See Appendix C for a full set of indicators and details about their measurement properties

during pregnancy (NVSS) and data on breastfeeding initiation and duration (NIS). Finally, rates of child maltreatment, which may influence physical health other child outcomes, are available through the National Child Abuse and Neglect Data System (NCANDS).

\subsection{Early cognition and language indicators}

In the early cognition and language domain, data are available from the NSCH about diagnoses of developmental delays (Table 3). Data are also available from the NSCH for certain cognitive/language developmental milestones (e.g., is the child able to use two words together). Parents of children of all ages are asked about developmental delays whereas the latter set of items are asked about children who are at least 1 year old.

Family/caregiver indicators of infant and toddler well-being related to the early cognition and language domain include $\mathrm{NSCH}$ data on caregiver interactions with the child (e.g., reading to children singing and telling stories to children) and whether a health care provider asked about concerns related to the child's learning or development.

\subsection{Early social-emotional-behavioral indicators}

The only nationally available child-level indicator of infant and toddler social-emotional-behavioral development is a battery of four items about flourishing designed to capture "curiosity and discovery about learning, resilience, attachment with parent(s), and contentment with life" (Table 4). These items are from the NSCH 
Table 4 Select infant and toddler social-emotional-behavioral development indicators available at the child or family/caregiver levels

Indicator

Primary source

Child indicators

Flourishing: Percent of infants and toddlers who meet the flourishing criteria based on a series of four items designed to capture curiosity and discovery about learning, resilience, attachment with parent, and contentment with life

Family/caregiver indicators

Adverse childhood experiences: Percent of infants and toddlers who have experienced at least one ACE (economic hardship, parent/guardian separated or divorced, parent/ guardian died, parent/guardian incarcerated, witnessed abuse, witness or victim of neighborhood violence, lived with someone mentally ill, lived with someone with drug/alcohol abuse, treated with racial/ethnic bias)

Family resilience: Percent of infants and toddlers who meet 4 family resilience items

Parental aggravation: Percent of infants and toddlers whose parents seldom feel aggravation from parenting

Father on birth certificate: Percent of babies for whom parents are married or there is paternal acknowledgement

$\mathrm{NSCH}$

$\mathrm{NSCH}$

$\mathrm{NSCH}$

$\mathrm{NSCH}$

NVSS

This is a select set of social-emotional-behavioral development indicators. See Appendix D for a full set of indicators and details about their measurement properties

and asked of parents of children 0-5 years (Child and Adolescent Health Measurement Initiative, 2018, p. 55). Information on family/caregiver indicators that may influence social-emotional-behavioral development-such as exposure to adverse childhood experiences (ACEs), parental aggravation, maternal mental health, family resilience, and eating meals together-are also available through the NSCH. Additionally, Vital Statistics indicates whether a father is listed on birth certificates.

\section{Discussion}

In this paper, we sought to identify indicators of infant and toddler well-being from the prenatal period to three years that are publicly available, comparable for all 50 states and DC, representative of state populations, and measured at regular time intervals. Most of the child-level indicators we identified were in the physical health domain. Relatively fewer child-level indicators were found in the early cognition and language and social-emotional-behavioral domains. These results highlight the need to develop a broader range of indicators of infant and toddler well-being and improve measurement sources to better inform policies and programs advancing population health.

\subsection{Strengths in existing infant and toddler indicators and measurement sources}

The indicators of infant and toddler well-being included in this review focus primarily on infant and toddler physical health. Indicators of physical health are crucial, as 
poor infant health can have lifelong consequences (Black et al., 2017). For example, research from Canada has found that health at birth is associated with infant mortality in the short term and educational success and reliance on social programs in the long term (Oreopoulos et al., 2008).

NVSS is the federal compilation of birth and death certificates from the 50 states, five U.S. territories, New York City, and the District of Columbia. A wealth of information is collected from birth certificates, including birthweight and length of gestation, parental characteristics, and health of the newborn. The NVSS is the only source of national population-level birth data on newborns, and it is large enough to facilitate subgroup comparisons (e.g., by race/ethnicity) within states. However, the reliability and validity of birth certificate data vary widely by individual item and those on maternal tobacco and alcohol use, prenatal care, pregnancy complications, delivery events, and congenital malformations have been identified as items that need quality improvement (Northam \& Knapp, 2006; Salemi et al., 2017). Additionally, analysts need to take into consideration changes in birth certificate designs over time when making historical comparisons.

The NIS and NSCH are surveys focused specifically on the health of children. The NIS-Child survey component is focused on immunization and breastfeeding histories among toddlers aged 19-35 months. The NSCH is more general-taking a whole child perspective - and captures health settings, behaviors, and outcomes for children ages $0-17$ years. It is the primary source of information on the well-being of infants and toddlers beyond immunizations, breastfeeding, and birth experiences. Both the NSCH and NIS are annual data collections with data that can be compared across states. Together, they cover many well-being indicators relevant to infants and toddlers.

\subsection{Challenges with existing infant and toddler indicators and measurements sources}

Indicators of infant and toddler early cognition and language and social-emotionalbehavioral development are more limited than those of physical health. Information needed to measure early cognition and language and social-emotional-behavioral development is frequently collected in clinical settings using child observations or parent questionnaires that capture rapid and interconnected changes in the early years. These clinical assessments are not easily scalable to population-level measurement due to the time and resource commitments needed for such data collection methods (Brito et al., 2019; Paschall et al., 2020). Nonetheless, NSCH has included questions on a child's understanding and use of language and measures of flourishing for children 0-5 years. Ideally, additional measures of early cognition and language and social-emotional-behavioral skills appropriate to children from birth to three years will become more readily available in future years.

Many of the available indicators reflect the absence of positive development (e.g., infant mortality rates, reported cases of child maltreatment) rather than the presence of positive development (e.g., normative language development, demonstrating curiosity) or the presence of supportive contexts for young children's development (e.g., 
positive parent-child or caregiver-child relationships). This dearth of "positive" indicators of child well-being has been an ongoing gap in the field for decades (Halle \& Moore, 1998; Lippman, 2007; Lippman et al., 2014; Moore \& Halle, 2001).

Even promising data sources have limitations. Sample sizes severely limit analysts' ability to disaggregate data to examine disparities by race/ethnicity and income at the state level with the NIS and NSCH in a timely manner. For example, the CDC combines multiple years of NIS data to produce its state-level cohort estimates of breastfeeding rates, without looking at subgroups (Centers for Disease Control and Prevention, National Center for Chronic Disease Prevention and Health Promotion, Division of Nutrition, Physical Activity, and Obesity, 2021). Additionally, the public-use version of the NIS contains only four racial/ethnic group identifiers: Hispanic, non-Hispanic Black, non-Hispanic other, and non-Hispanic White, limiting analysts' ability to examine smaller racial/ethnic subgroups (Centers for Disease Control and Prevention, National Center for Immunization and Respiratory Diseases, 2020). The last time the Current Population Survey produced estimates of food insecurity in households with children at the state level, it combined data from 2003 to 2011 to do so (Coleman-Jensen et al., 2013). With the NSCH, subgroup analyses are limited by sample size that is compounded by a survey redesign. The NSCH survey administration methodology was redesigned in 2016, and data before and after the redesign cannot be harmonized, limiting the number of years of data that can be combined (U.S. Census Bureau, 2021a).

Other data sources did not meet our inclusion criteria. For instance, family/ caregiver indicators in the Behavioral Risk Factor Surveillance System (BRFSS) cannot be disaggregated for children from the prenatal period to age three. The Pregnancy Risk Assessment Monitoring System (PRAMS), National Health and Nutrition Examination Survey (NHANES), and National Health Interview Survey (NHIS) have indicators for infant and toddler well-being, but data are either not publicly available or not representative of state populations. Newborn screenings are not systemically measured so comparability across states is unclear. Further, administrative data can supply information on the number of children or families receiving varied services and benefits; however, these systems only include those receiving services and do not measure indicators for children who may be at-risk for adverse outcomes.

\subsection{Ways to address challenges with child indicators and measurement sources}

There are promising examples of ways to address the challenges with existing indicators and measurement sources highlighted in this report. In recent years, the World Health Organization developed the Global Scale for Early Development (GSED), a population-level measure of child development for children at birth to age three. The GSED is currently being validated in several countries, including the United States, with the goal of accelerating early childhood development monitoring (Black et al., 2019). Many European countries have population registries that provide basic data about all individuals, including infants and toddlers, that can be aggregated across communities. Data collected from 
these sources are shared with governments, schools, and community leaders to help make informed policy and program decisions that address the needs of all children.

Some states in the United States have also developed ways to address the challenges with existing child indicators and measurement sources. For example, several states have started a process to include home visiting data within early childhood integrated data systems (Lin, 2019). The long-term goal of these efforts is to gain a comprehensive understanding of child and family access to the programs and services infants and toddlers have received. Minnesota's Early Childhood Longitudinal Data System (ECLDS) links data from the state departments of Education, Human Services, and Health. Using a public online platform, data users can access deidentified aggregate-level reports on topics such as birth records, program participation, financial assistance programs, and child and family demographics (Jordan et al., 2018). These efforts hold promise for linking administrative data with data about young children and their families, yet they are not at the stage where they include indicators of young children's development.

Other communities across the United States are exploring ways to use developmental screeners such as the Ages and Stages Questionnaire (ASQ) to create a proxy for understanding whether infants and toddlers are developmentally "on track." Developmental screeners cannot be used for diagnosis, but they can be effective in identifying the need for further assessment. Tracking assessment after developmental screening is complex and requires collaboration and coordination between practitioners, providers, and stakeholders. Efforts in Salt Lake City, Utah; Tarrant County, Texas; and Norwalk, Connecticut are being made to build partnerships, address data coordination challenges, and explore the viability of using screeners as population measures of infant and toddler development (K. Paschall, personal communication, November 4, 2021).

There may also be an opportunity to aggregate data in the United States in a similar fashion to European registries. Most infants and toddlers in the United States receive well-child check-ups (Keating et al., 2020). Information collected at these visits, such as timing of meeting developmental milestones, could theoretically be aggregated. This type of data linkage would be complex and would require integrating medical records across multiple data systems, using a shared data management platform, ensuring that data are de-identified in compliance with HIPAA, and following other relevant regulations. The de-identified, aggregate data source would then be a rich source of information on infant and toddler health and development.

\subsection{Ways to prioritize future child indicator development and measurement efforts}

We recognize that data collection efforts are extremely complex and expensive. There are ways to prioritize indicators collected through existing and upcoming data collection efforts when resources are limited. Here we focus on three considerations 
relevant to children's outcomes: (i) prevalence, (ii) severity, and (iii) disparate impacts.

Children's health has traditionally been assessed by evaluating indices that include the prevalence of adverse health conditions (e.g., proportion of newborns born small or too early), with a focus on discovering associations and finding effective prevention methods (NRC \& IOM, 2004). The prevalence of typical child development is more prevalent than atypical child development, yet measures of appropriate developmental achievements appropriate for children from birth to three years are limited. Balancing indicators that measure adverse health outcomes, typical child development, and supportive contexts may help improve state-based monitoring for all children, including those who are at-risk versus presently demonstrating atypical development.

Another way of prioritizing the development of new indicators is to focus on factors that can severely impact subsequent development. Some measurement sources in this review collect data about conditions that can severely impact development, such as low birthweight or maltreatment. However, we lack comprehensive statelevel measures on other potentially damaging conditions, such as malnutrition or psychosocial deprivation (Black et al., 2017). An important consideration when thinking about these types of indicators is whether social desirability bias prevents data from being accurately collected, as disclosing these conditions may be difficult for respondents.

Finally, some outcomes may be more impactful in vulnerable populations, raising equity concerns. A core principle of various indicators frameworks is to promote health equity (Raikes et al., 2017; Black et al., 2019). One example is the UNICEF "human rights-based approach" of selecting indicators for the child-related Sustainable Development Goals (SDG) that realize the rights of every child, especially the most disadvantaged. Measuring differences in well-being indicators across demographic subgroups can inform policy and program decisions to address health disparities. For instance, it is well known that maternal and child health inequities emerge even before birth in the United States (Wilkinson et al., 2021). Nationally representative studies find that measures of child development such as self-regulation or early learning skills vary by race and ethnicity by kindergarten (Piña et al., 2020), with differences even emerging by nine months (Halle et al., 2009). Yet, state-level data on these outcomes are limited for population subgroups.

Investing in resources to increase sample sizes and provide representative and comparable data across states could expanded opportunities for health disparity research. The NSCH has been able to increase its sample sizes through optional state oversamples, both of entire states and of more specific geographic areas. The NSCH costs approximately $\$ 16.82$ per sampled address, but that is not the total cost per response, since an average of approximately six addresses must be sampled to achieve one completed response. Using a hypothetical example provided by the $\mathrm{NSCH}$, it would cost a state about $\$ 58,870$ to double their sample size (U.S. Census Bureau, 2021b). Among the 12 states that have or are currently sponsoring an oversample, actual costs for state oversamples have ranged from approximately $\$ 20,000$ to $\$ 500,000$ (A. Hirai, personal communication, October 22, 2021). Additionally, the CDC co-sponsored the $2021 \mathrm{NSCH}$ in order to support a national increase in 
the sample size of children ages $1-5$ years. The NSCH is also exploring options to improve state-level sample sizes for underrepresented racial/ethnic populations (A. Hirai, personal communication, October 22, 2021).

In other cases, current sampling procedures limit data sources' ability to be easily expanded. The NIS, for example, is a phone-based survey targeting a very small proportion of the population (as respondents need to have a toddler ages 19-35 months for the child survey). The CPS Food Security Supplement is an add-on to the CPS and is dependent on the CPS sampling frame. Expanding the sample of either the NIS or the CPS Food Security Supplement would be very resource intensive. The $\mathrm{NSCH}$ is also exploring options to adapt its sampling to be able to target specific groups of children (A. Hirai, personal communication, October 22, 2021).

Recent national efforts have been established to prioritize equitable data collection and reporting. In January 2021, President Joe Biden signed an executive order to establish an Interagency Working Group on Equitable Data. This group will identify weaknesses in federal data collection efforts and help agencies expand and improve their data collection efforts (Exec. Order No. 13985, 2021). Additionally, the Robert Wood Johnson Foundation has established a National Commission to Transform Public Health Data Systems, aiming to rethink and improve the public health data system to promote health equity.

\section{Conclusions}

The first three years of life are critically important for a child's development. Statelevel indicators can be used to monitor the well-being of infants and toddlers, monitor the equity of well-being across sub-populations, and inform policies and programming to promote child well-being. Indicators that are publicly available, comparable across states, representative of state populations, and measured at regular time intervals are primarily focused on physical health and lack indicators of infant and toddler development in other important domains essential to child wellbeing (early cognition and language and social-emotional-behavioral development; The Alliance for Child Protection in Humanitarian Action, 2021). While many states are making progress toward developing integrated early childhood data systems, more work is needed to provide robust data on indicators of nurturing care that facilitate infant and toddler development (World Health Organization, United Nations Children's Fund, World Bank Group, 2018). Investing in comprehensive data collection efforts that balance adverse outcomes, typical child development, and supportive contexts may help improve state-based monitoring for all children. These data collection efforts could more fully support infants and toddlers as well as the parents, providers, and policymakers working to foster their development. 


\section{Appendix A. Potential indicators of infant and toddler development identified in literature review}

\begin{tabular}{l} 
Child indicators \\
\hline Physical health \\
Poor in-utero health \\
Low birthweight \\
Preterm birth \\
Abnormal conditions of newborn \\
Congenital abnormalities \\
APGAR score \\
Infant mortality \\
Overweight or underweight, obesity, weight-for- \\
length \\
Poor oral health \\
Physical health \\
Physical activity \\
Physical activity \\
Immunizations \\
Chronic illness \\
Unintentional injury \\
Special health care needs (SHCN) status ${ }^{\text {b }}$
\end{tabular}

Social-emotional-behavioral development

Flourishing (National Survey of Children's Health $[\mathrm{NSCH}]$ definition: healthy attachment, curiosity, bouncing back, positive affect expression)
Family/caregiver indicators $^{\mathrm{d}}$

Maltreatment (abuse and neglect)

Early childhood adversity ${ }^{\mathrm{a}}$

Exposure (victim/witness) to family-domestic violence (intimate partner violence, child maltreatment)

Health insurance coverage

Medicaid coverage

Medical home

Medical care visit

Gestational diabetes and maternal infections during pregnancy

Insufficient folic acid during pregnancy

Insufficient vitamin D during pregnancy

Pregnancy complications

Prenatal care

Maternal or paternal mental health

Maternal smoking, drinking, or drug use

Maternal BMI (pre-natal)

Maternal BMI (post-natal)

Maternal mortality

Maternal morbidity

Breastfeeding initiation and duration

Diet high in sugar and/or fat

Malnutrition

Food security

Dental care visit

Vision test

Sleep conditions (consistency and position)

Younger or older parental age

Parental substance use

Exposure to environmental toxins (e.g., pollutants in homes, second-hand smoke exposure, lead, organophosphates, mercury exposure/poisoning)

Housing stability and quality ${ }^{\mathrm{c}}$

Unintended pregnancy

Family planning

Adverse childhood experiences (ACEs): Caregiver exposure 
Child indicators

Curiosity, exploration, or novelty-seeking

Emotion regulation or expression skills

Self-regulation skills

Negative emotionality

Active temperament

Emotional withdrawal

Approach, sociability, attention, or activity level

Attachment

Reaching developmental milestones

\section{Early cognition and language}

Cognitive/language development

Developmental delay
Family/caregiver indicators $^{\mathrm{d}}$

ACEs: Child exposure

Exposure to child welfare system

Shared family meals

Family resilience

Parental aggravation

Parental conflict

Family instability, turbulence

Parenting (disengaged, punitive, harsh, authoritative; positive; co-parenting)

Parental marital status

Father on birth certificate

Parental employment

Parental education attainment

Social capital

Social support (family, friends)

Unemployment rate

Parent training in child development milestones

Parent-child education program

Developmental surveillance

Developmental screening

Teacher training on children's developmental stages

Healthcare provider training on developmental screening

Language-rich environment and caregiver communication (reading/singing/telling stories exposure)

Excessive screen time ( $>2 \mathrm{~h}$ per weekday)

Access to high-quality, affordable child care

High-quality ECE program dosage (days per week, months per year, etc.)

Attendance in a high-quality early childhood education (ECE) program

Child care instability

Family poverty

Family members with mental health issues or SHCN status

${ }^{a}$ Early childhood adversity is used as a catch-all term in the literature to capture all or some factors of adverse childhood experiences (ACES) and toxic stress. Early childhood adversities capture broad concepts (e.g., demographic, sociological, and prenatal exposures to trauma and developmental issues)

${ }^{\mathrm{b}}$ We recognize the overlaps between developmental delay and special health care needs (SCHN) as well as the complexities of identifying and serving these needs for the 0-3 age group

${ }^{c}$ Housing stability and housing instability are catch-all terms that capture the impacts of issues such as crowding, frequency of moves, homelessness, and cost burden of home expenses

${ }^{\mathrm{d}}$ Many of the child-level and family/caregiver indicators are related to multiple developmental domains. They are listed in the most relevant domain to save space 


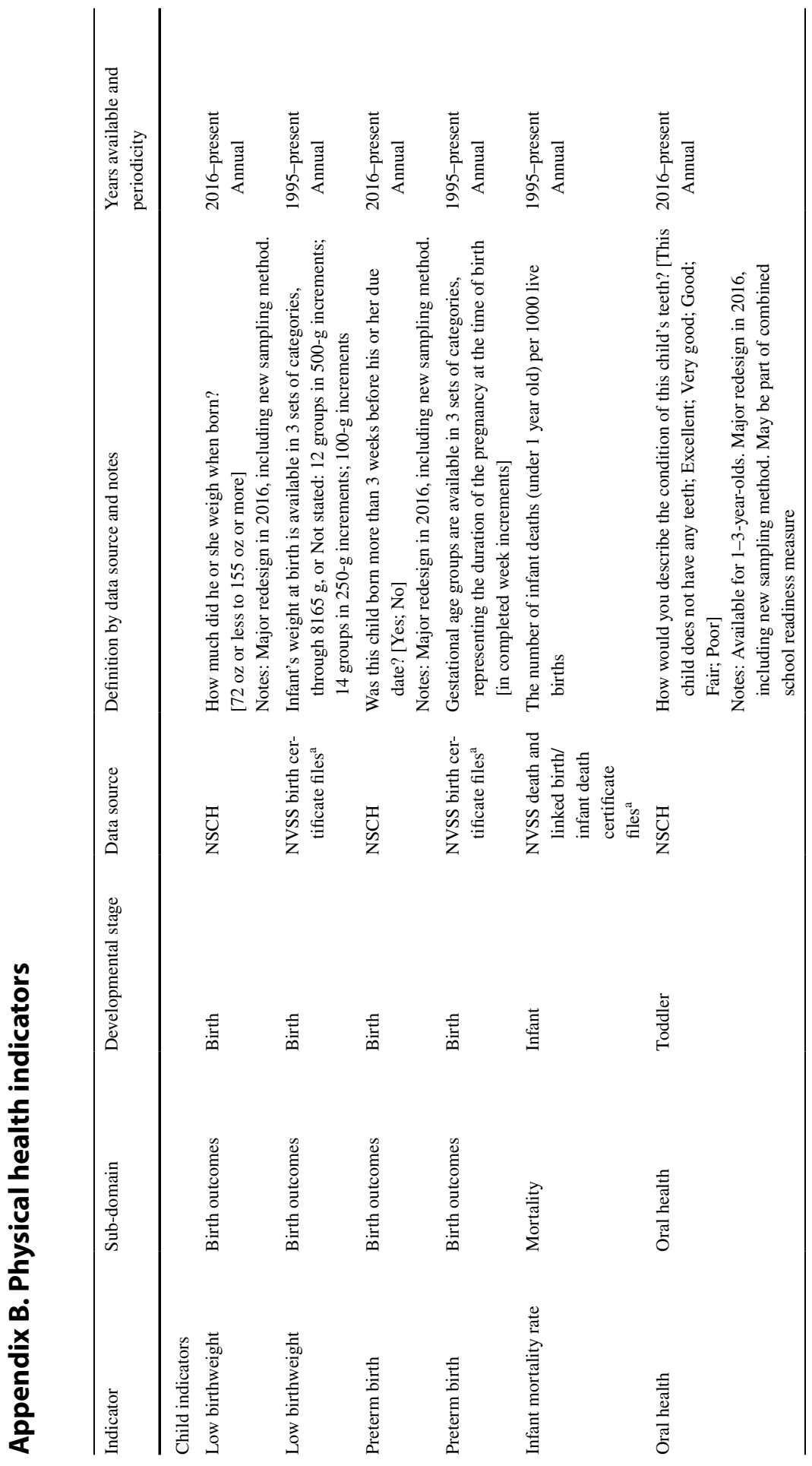




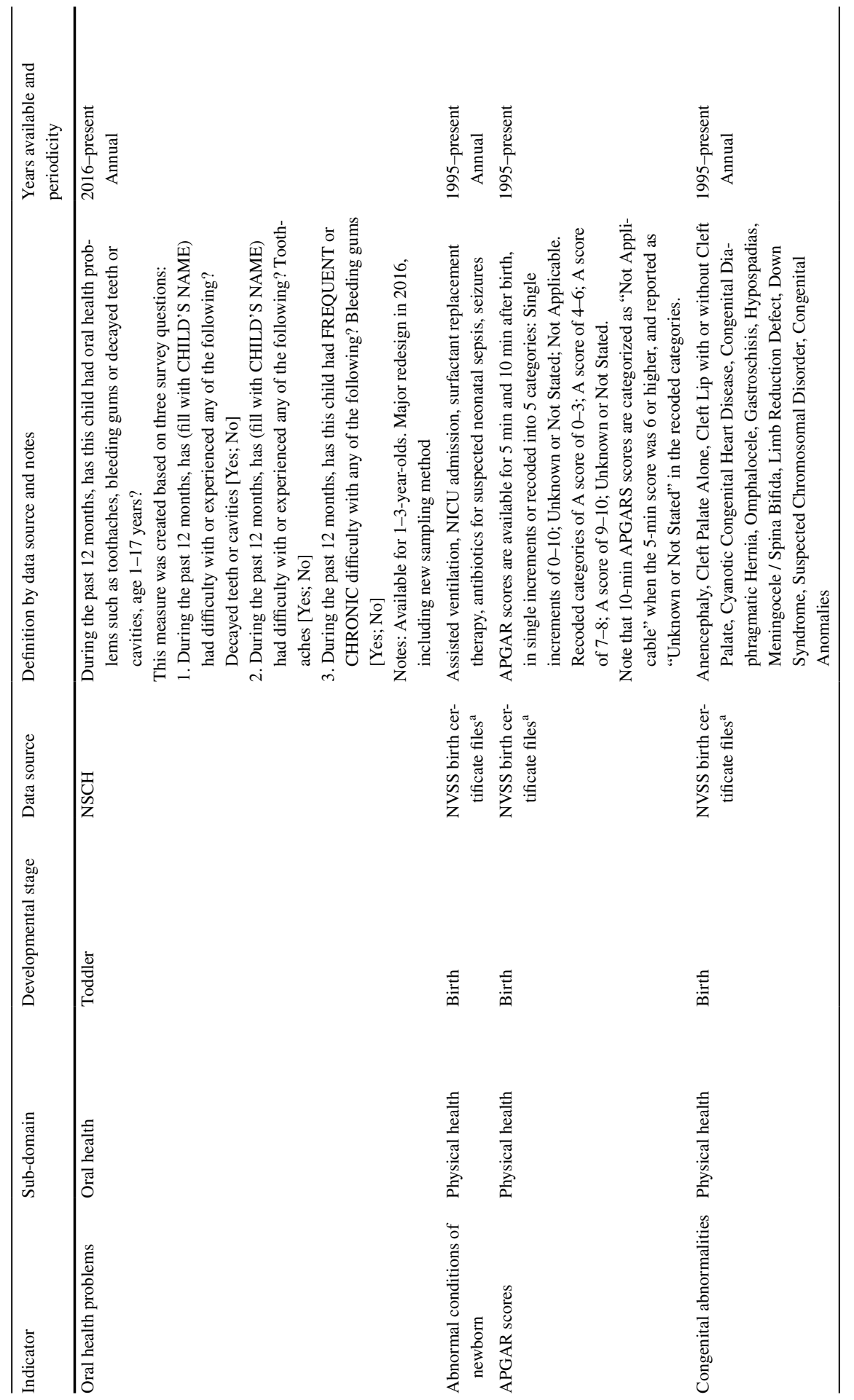




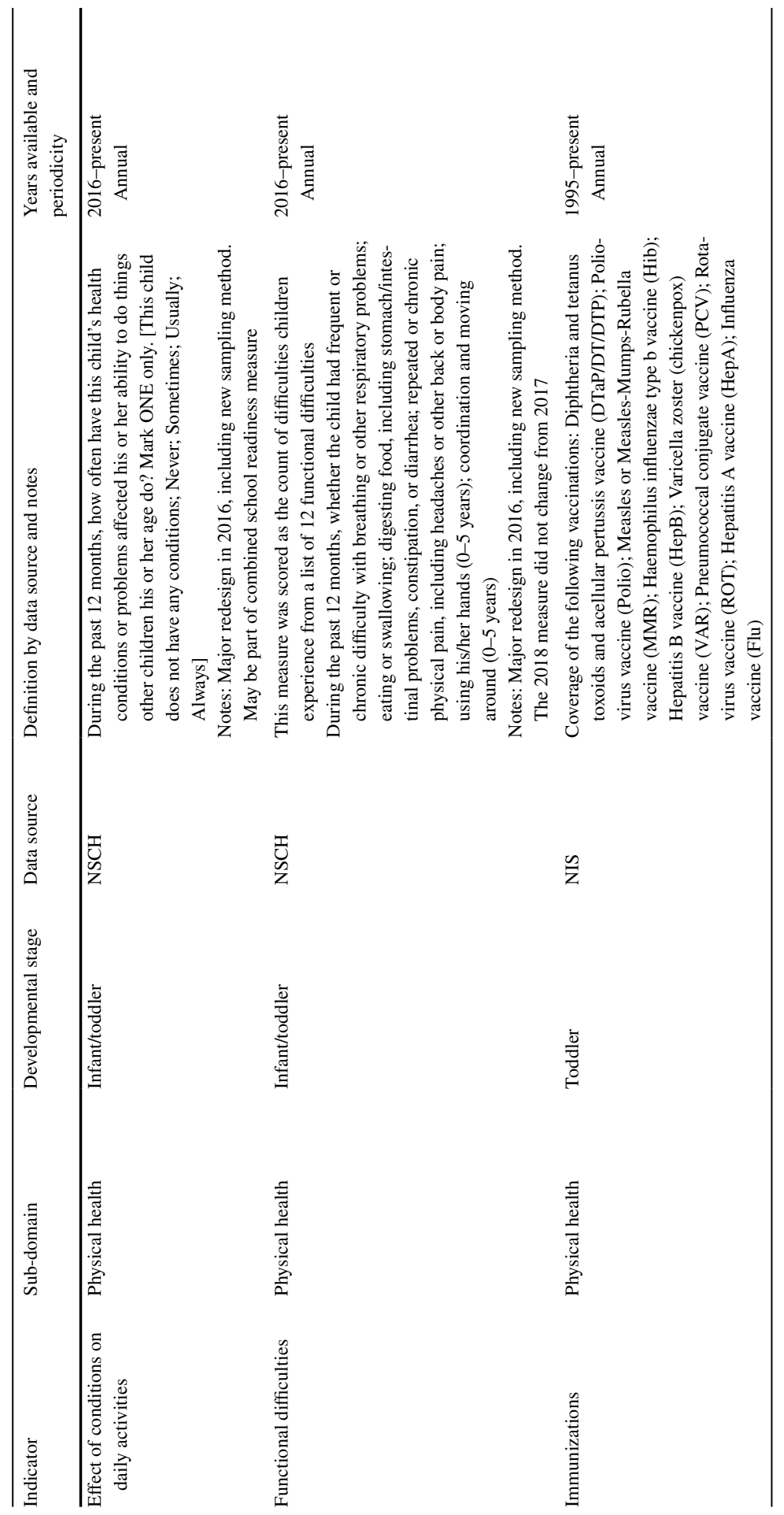




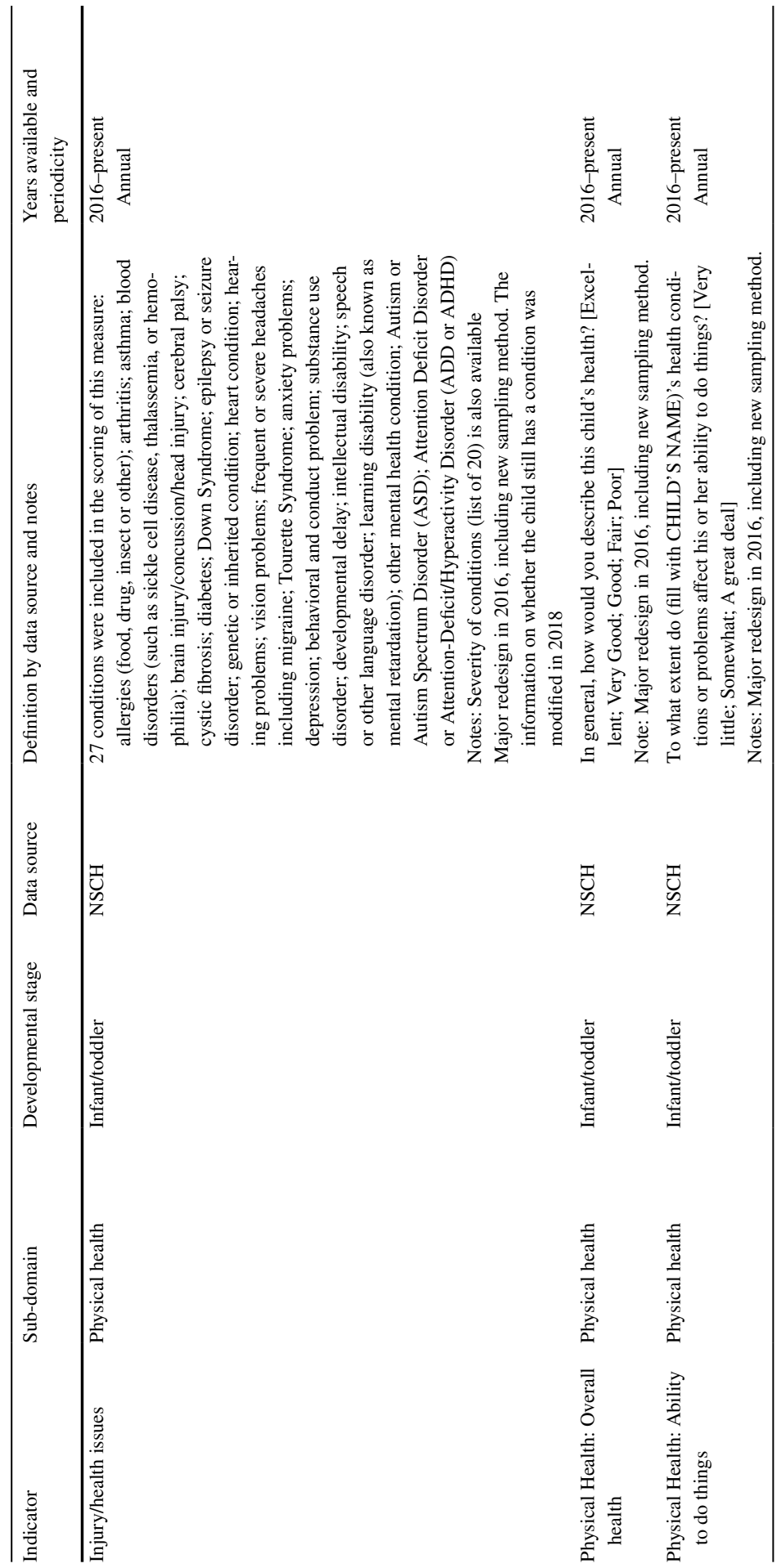




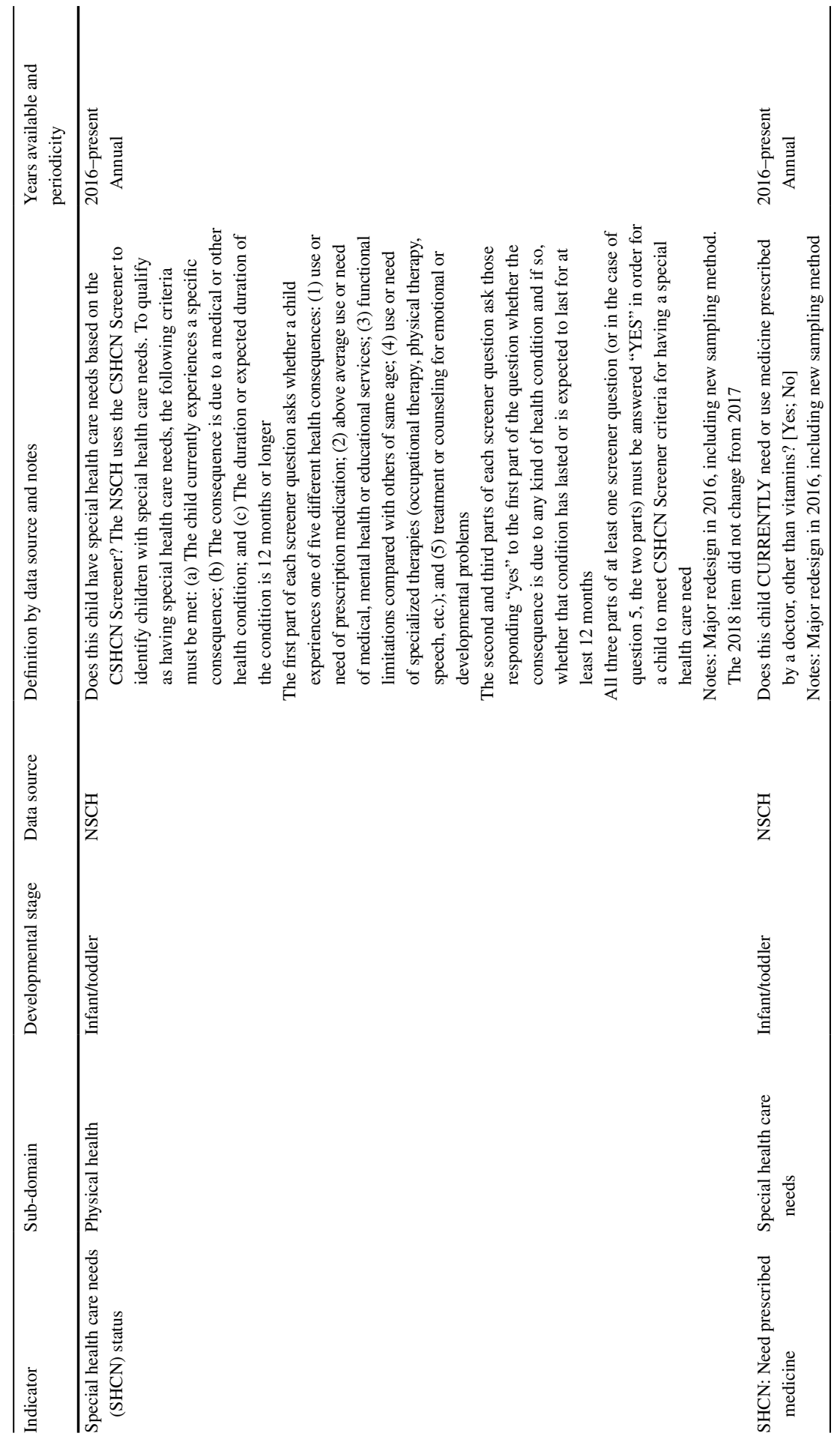




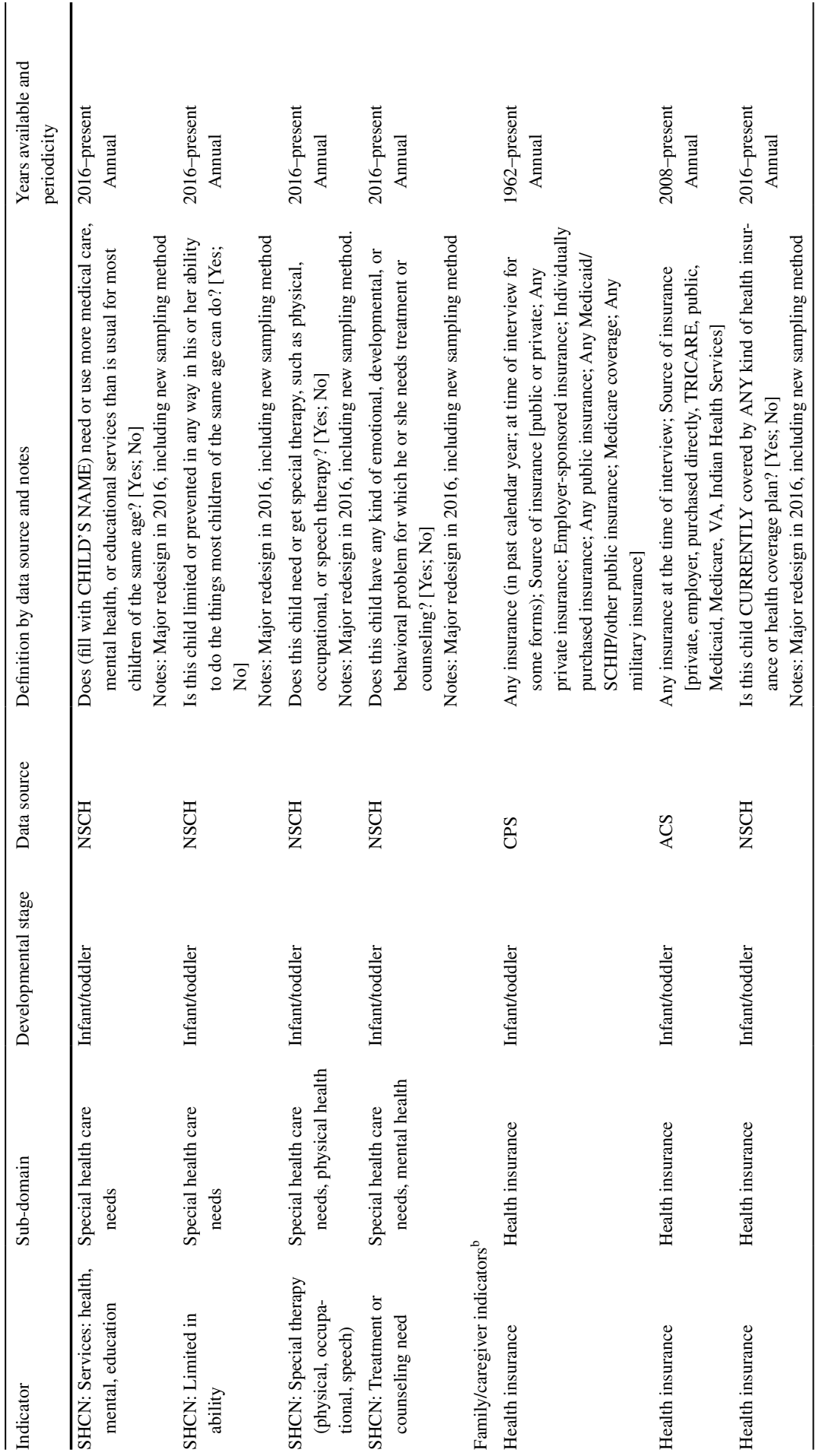




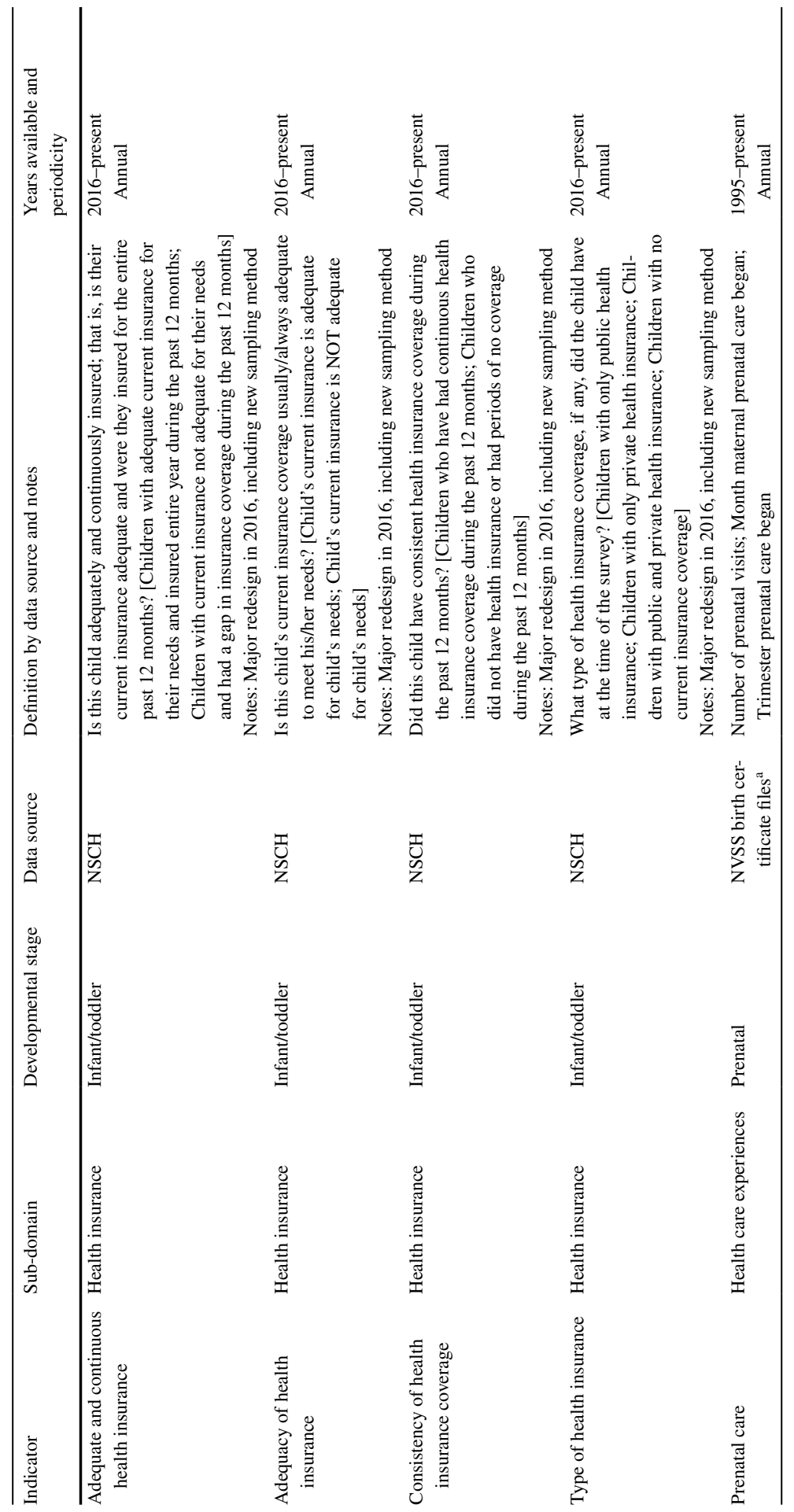




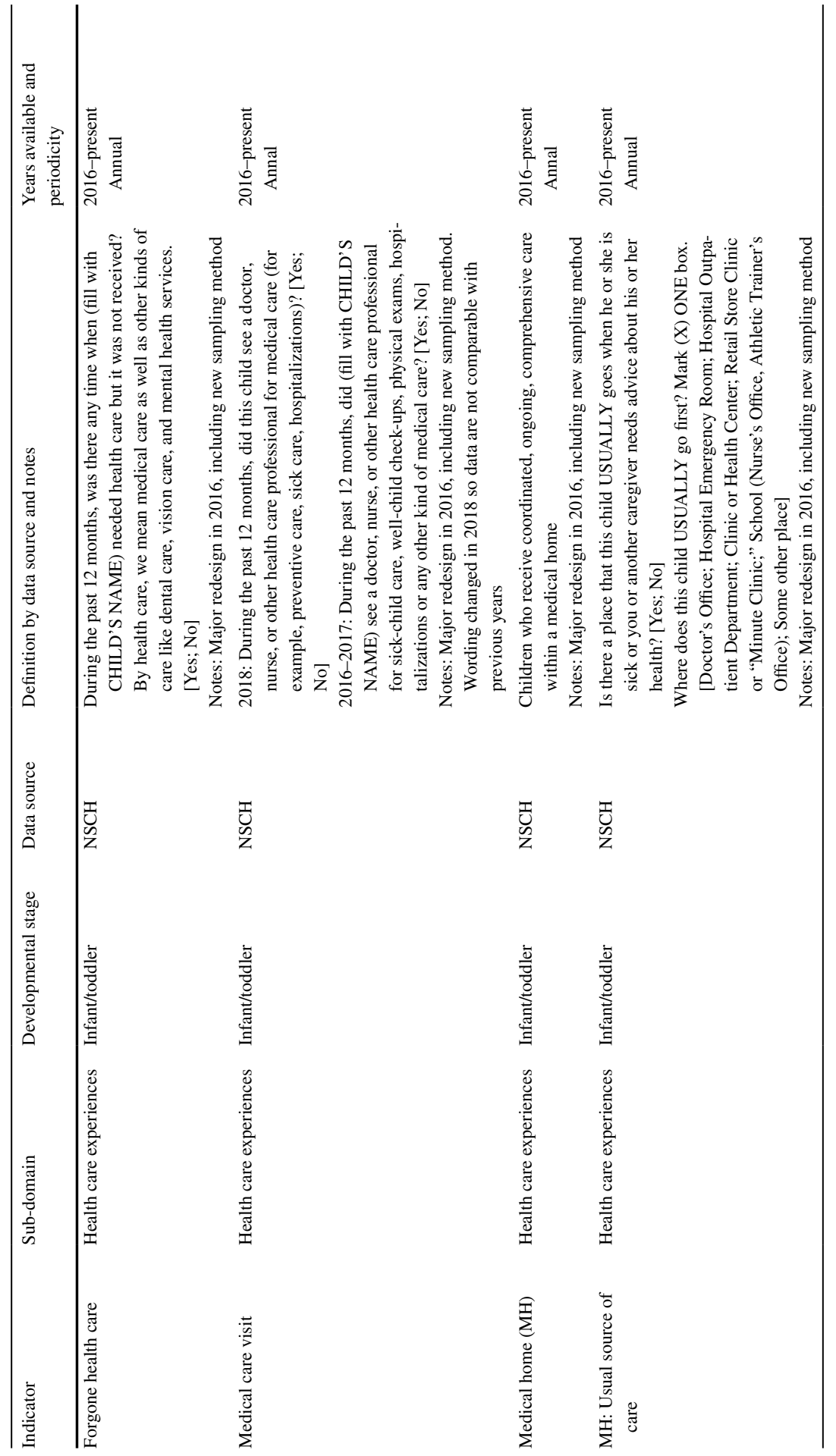




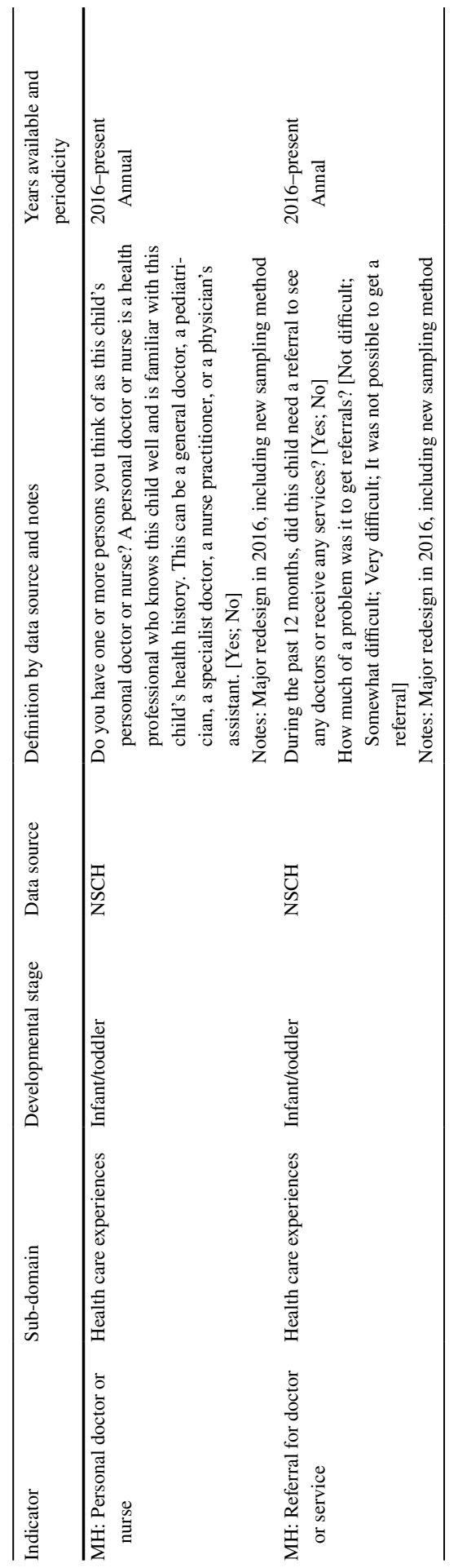




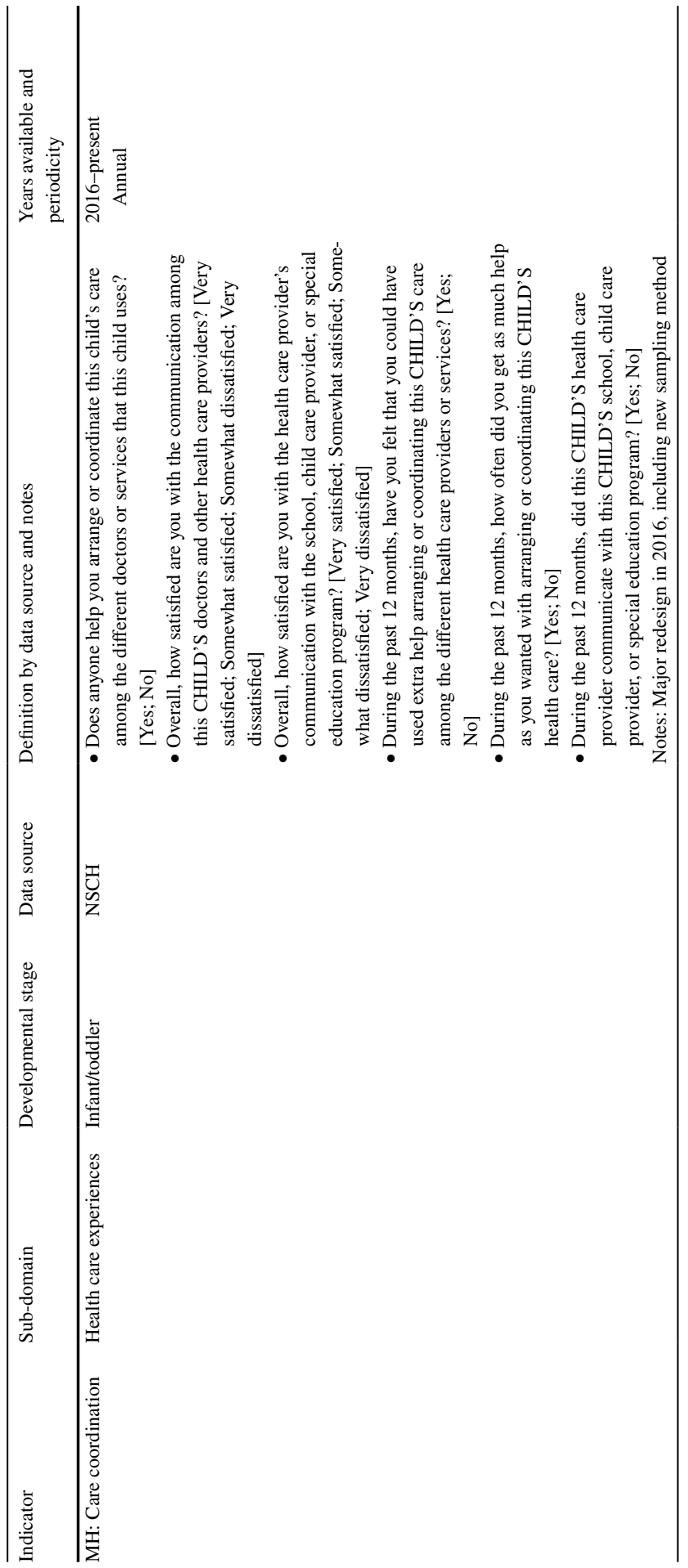




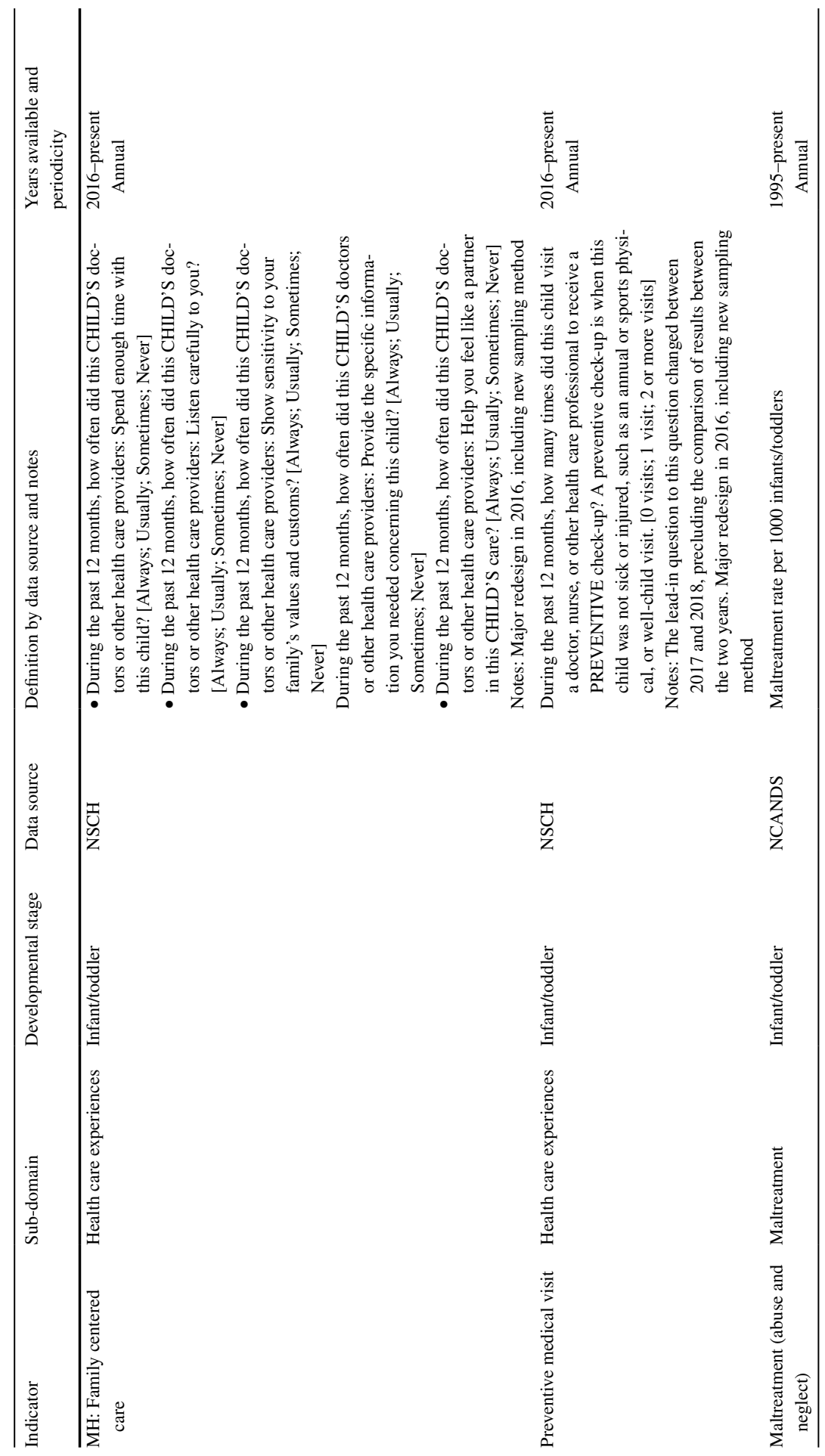




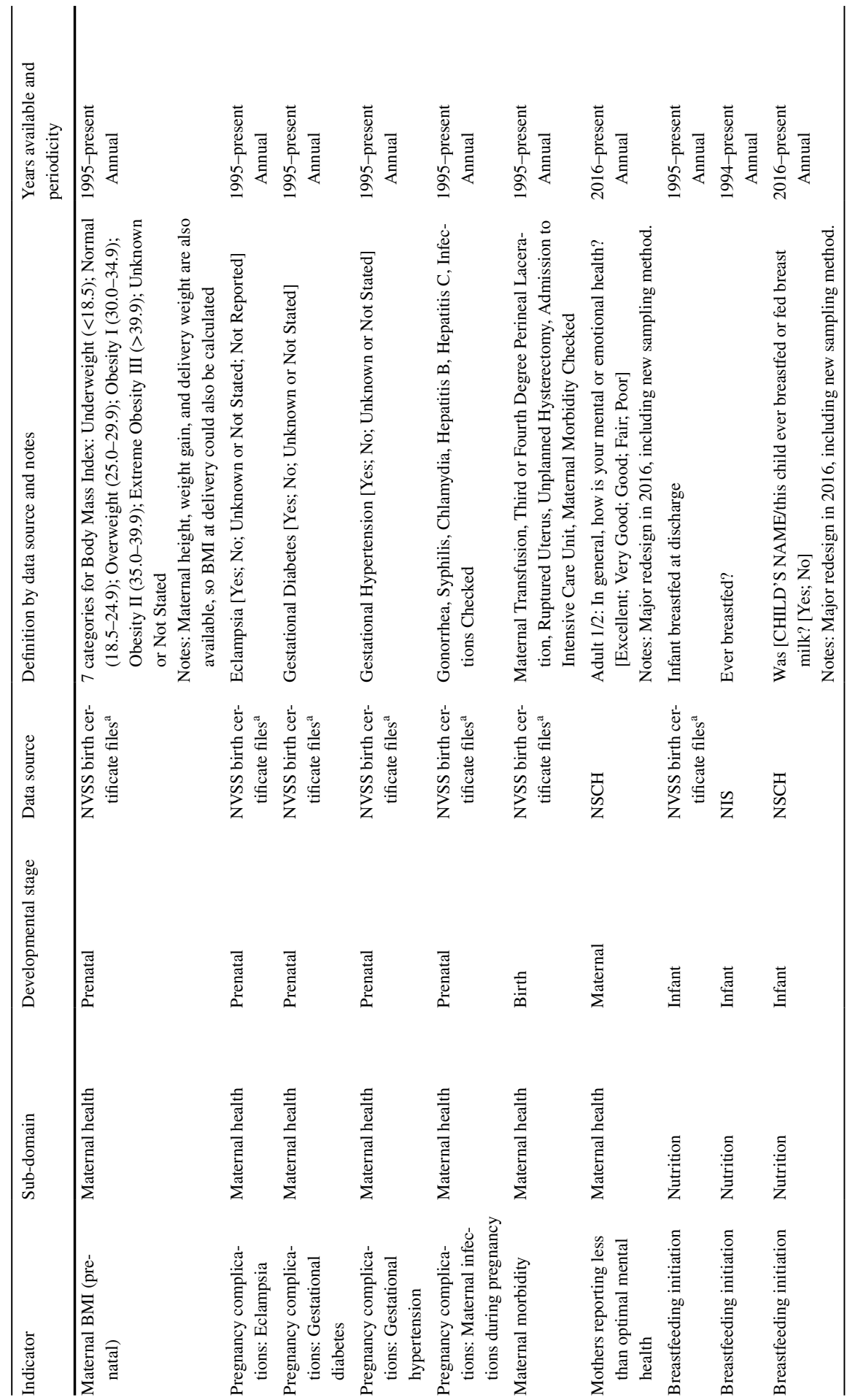




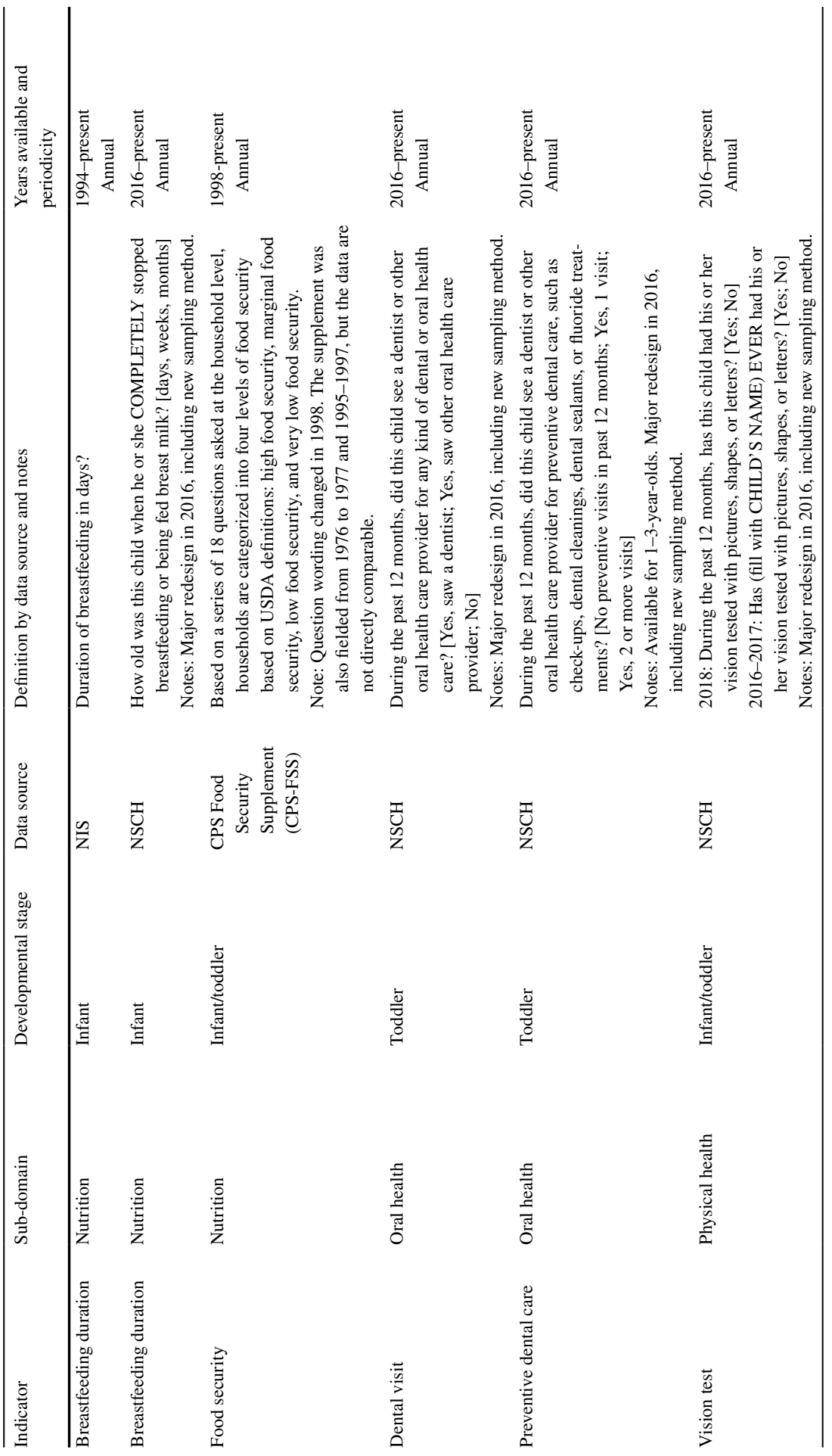




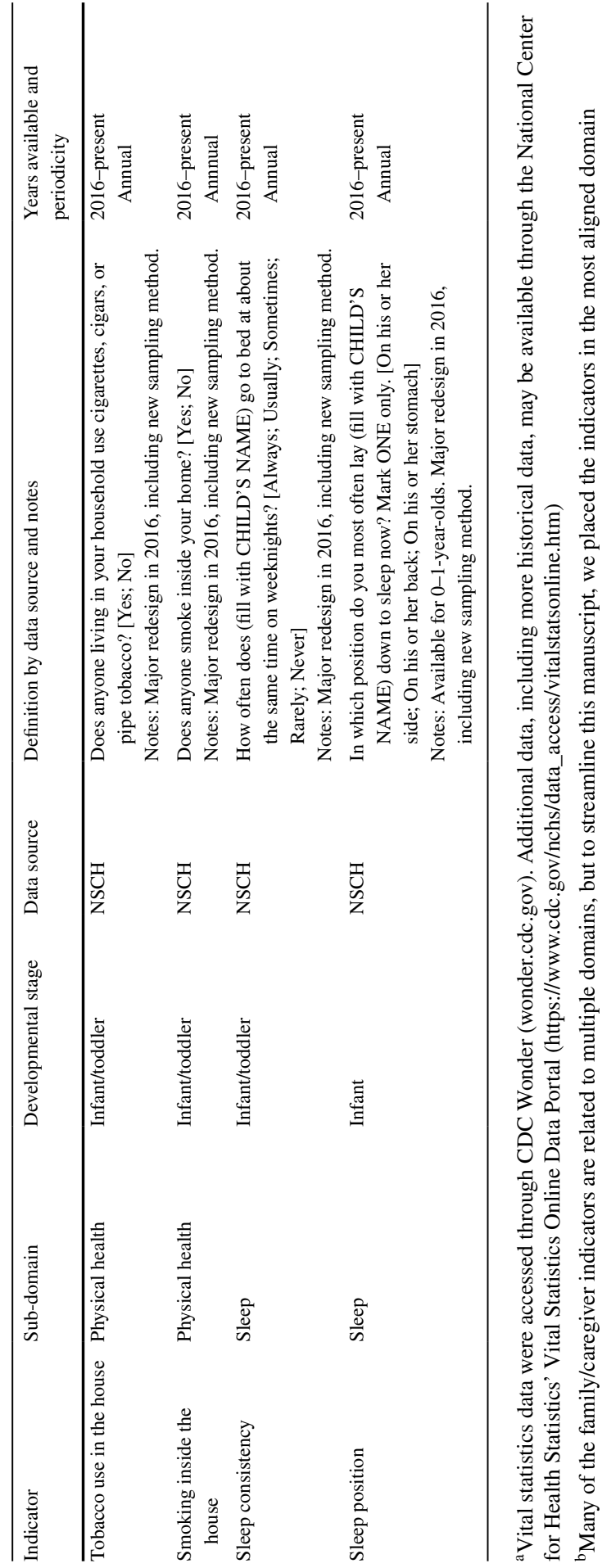




\section{Appendix C. Early cognition and language indicators}

\begin{tabular}{|c|c|c|c|c|c|}
\hline Indicator & Subdomain & $\begin{array}{l}\text { Develop- } \\
\text { mental } \\
\text { stage }\end{array}$ & $\begin{array}{l}\text { Data } \\
\text { source }\end{array}$ & Definition by data source and notes & $\begin{array}{l}\text { Years avail- } \\
\text { able and } \\
\text { periodicity }\end{array}$ \\
\hline
\end{tabular}

\begin{tabular}{|c|c|c|c|c|c|}
\hline \multicolumn{6}{|l|}{ Child indicators } \\
\hline $\begin{array}{l}\text { Cognitive/ } \\
\text { language } \\
\text { development }\end{array}$ & N/A & $\begin{array}{l}\text { Infant/tod- } \\
\text { dler }\end{array}$ & $\mathrm{NSCH}$ & $\begin{array}{l}\text { Is this child able to do the following...? } \\
\text { - Say at least one word, such as "hi" or } \\
\text { "dog." } \\
\text { - Use } 2 \text { words together, such as "car go." } \\
\text { - Use } 2 \text { words together, such as "car go." } \\
\text { - Use } 2 \text { words together, such as "car go." } \\
\text { - Use } 3 \text { words together in a sentence, such } \\
\text { as, "Mommy come now." } \\
\text { - Ask questions like "who," "what," } \\
\text { "when," "where." } \\
\text { - Ask questions like "why" and "how." } \\
\text { - Tell a story with a beginning, middle, } \\
\text { and end. } \\
\text { - Understand the meaning of the word "no." } \\
\text { - Follow a verbal direction without hand } \\
\text { gestures, such as "Wash your hands." } \\
\text { - Point to things in a book when asked. } \\
\text { - Follow 2-step directions, such as "Get } \\
\text { your shoes and put them in the basket." } \\
\text { - Understand words such as "in," "on," and } \\
\text { "under." } \\
\text { Notes: Major redesign in } 2016, \text { including } \\
\text { new sampling method. These questions } \\
\text { were asked to children ages } 1-5 \text { years } \\
\text { only. }\end{array}$ & $\begin{array}{c}\text { 2016-present } \\
\text { Annual }\end{array}$ \\
\hline $\begin{array}{l}\text { Developmental } \\
\text { delays }\end{array}$ & N/A & $\begin{array}{l}\text { Infant/tod- } \\
\text { dler }\end{array}$ & $\mathrm{NSCH}$ & $\begin{array}{l}\text { Has a doctor, other health care provider, or } \\
\text { educator EVER told you that (fill with } \\
\text { CHILD'S NAME) has... Developmental } \\
\text { Delay? Examples of educators are teach- } \\
\text { ers and school nurses. [Yes; No] } \\
\text { Notes: Major redesign in 2016, including } \\
\text { new sampling method. }\end{array}$ & $\begin{array}{c}\text { 2016-present } \\
\text { Annual }\end{array}$ \\
\hline \multicolumn{6}{|c|}{ Family/caregiver indicators ${ }^{\mathrm{a}}$} \\
\hline $\begin{array}{c}\text { Developmental } \\
\text { surveillance }\end{array}$ & N/A & $\begin{array}{l}\text { Infant/tod- } \\
\text { dler }\end{array}$ & $\mathrm{NSCH}$ & $\begin{array}{l}\text { During the past } 12 \text { months, did this child's } \\
\text { doctors or other health care providers ask } \\
\text { if you have concerns about this child's } \\
\text { learning, development, or behavior? [Yes; } \\
\text { No] } \\
\text { Notes: This is the often-forgotten half of } \\
\text { the AAP guidance. Screening is not as } \\
\text { effective without this surveillance. Major } \\
\text { redesign in 2016, including new sampling } \\
\text { method. }\end{array}$ & $\begin{array}{c}\text { 2016-present } \\
\text { Annual }\end{array}$ \\
\hline
\end{tabular}




\begin{tabular}{|c|c|c|c|c|c|}
\hline Indicator & Subdomain & $\begin{array}{l}\text { Develop- } \\
\text { mental } \\
\text { stage }\end{array}$ & $\begin{array}{l}\text { Data } \\
\text { source }\end{array}$ & Definition by data source and notes & $\begin{array}{l}\text { Years avail- } \\
\text { able and } \\
\text { periodicity }\end{array}$ \\
\hline $\begin{array}{l}\text { Developmental } \\
\text { screening }\end{array}$ & N/A & $\begin{array}{l}\text { Infant/tod- } \\
\text { dler }\end{array}$ & $\mathrm{NSCH}$ & $\begin{array}{l}\text { During the past } 12 \text { months, did a doctor or } \\
\text { other health care provider have you or } \\
\text { another caregiver fill out a questionnaire } \\
\text { about observations or concerns you may } \\
\text { have about this child's development, } \\
\text { communication, or social behaviors? } \\
\text { Sometimes a child's doctor or other health } \\
\text { care provider will ask a parent to do this at } \\
\text { home or during a child's visit. [Yes; No] } \\
\text { Notes: Available for ages } 10 \text { months - } \\
3 \text { years. Major redesign in } 2016 \text {, including } \\
\text { new sampling method. }\end{array}$ & $\begin{array}{c}\text { 2016-present } \\
\text { Annual }\end{array}$ \\
\hline $\begin{array}{c}\text { Reading to } \\
\text { children }\end{array}$ & N/A & $\begin{array}{l}\text { Infant/tod- } \\
\text { dler }\end{array}$ & $\mathrm{NSCH}$ & $\begin{array}{l}\text { During the past week, how many days did } \\
\text { you or other family members read to this } \\
\text { child? [0 days; } 1-3 \text { days; } 4-6 \text { days; Every } \\
\text { day] } \\
\text { Notes: Major redesign in 2016, including } \\
\text { new sampling method. }\end{array}$ & $\begin{array}{c}\text { 2016-present } \\
\text { Annual }\end{array}$ \\
\hline $\begin{array}{l}\text { Singing and tell- } \\
\text { ing stories }\end{array}$ & N/A & $\begin{array}{l}\text { Infant/tod- } \\
\text { dler }\end{array}$ & $\mathrm{NSCH}$ & $\begin{array}{l}\text { During the past } 12 \text { During the past week, } \\
\text { how many days did you or other family } \\
\text { members tell stories or sing songs to this } \\
\text { child? [0 days; } 1-3 \text { days; } 4-6 \text { days; Every } \\
\text { day] } \\
\text { Notes: Major redesign in } 2016 \text {, including } \\
\text { new sampling method. }\end{array}$ & $\begin{array}{c}\text { 2016-present } \\
\text { Annual }\end{array}$ \\
\hline Screen time & N/A & $\begin{array}{l}\text { Infant/tod- } \\
\text { dler }\end{array}$ & $\mathrm{NSCH}$ & $\begin{array}{l}\text { 2018: ON MOST WEEKDAYS, about how } \\
\text { much time did this child spend in front of } \\
\text { a TV, computer, cellphone or other elec- } \\
\text { tronic device watching programs, playing } \\
\text { games, accessing the internet, or using } \\
\text { social media? [Less than } 1 \mathrm{~h} ; 1 \mathrm{~h} ; 2 \mathrm{~h} ; 3 \mathrm{~h} \text {; } \\
4 \text { or more hours] } \\
\text { 2016-2017: ON AN AVERAGE WEEK- } \\
\text { DAY, about how much time does (fill with } \\
\text { CHILD'S NAME) usually spend in front } \\
\text { of a TV watching TV programs, videos, } \\
\text { or playing video games? [None; Less than } \\
1 \text { h; } 1 \text { h; } 2 \text { h; } 3 \text { h; } 4 \text { or more hours] } \\
\text { 2016-2017: ON AN AVERAGE WEEK- } \\
\text { DAY, about how much time does (fill with } \\
\text { CHILD'S NAME) usually spend with } \\
\text { computers, cell phones, handheld video } \\
\text { games, and other electronic devices, doing } \\
\text { things other than schoolwork? [None; } \\
\text { Less than } 1 \text { h; } 1 \text { h; } 2 \text { h; } 3 \text { h; } 4 \text { or more } \\
\text { hours] } \\
\text { Notes: Major redesign in } 2016 \text {, including } \\
\text { new sampling method. }\end{array}$ & $\begin{array}{l}\text { 2016-present } \\
\text { Annual }\end{array}$ \\
\hline
\end{tabular}

${ }^{a}$ Many of the family/caregiver indicators are related to multiple domains, but to streamline this manuscript, we placed the indicators in the most aligned domain 


\section{Appendix D. Social-emotional-behavioral development indicators}

\begin{tabular}{|c|c|c|c|c|c|}
\hline Indicator & $\begin{array}{l}\text { Subdo- } \\
\text { main }\end{array}$ & $\begin{array}{l}\text { Developmen- } \\
\text { tal stage }\end{array}$ & $\begin{array}{l}\text { Data } \\
\text { source }\end{array}$ & Definition by data source and notes & $\begin{array}{l}\text { Years available } \\
\text { and periodicity }\end{array}$ \\
\hline \multicolumn{6}{|l|}{ Child indicators } \\
\hline Flourishing & N/A & Infant/toddler & $\mathrm{NSCH}$ & $\begin{array}{l}\text { For children age } 0-5 \text { years, four questions } \\
\text { were asked that aimed to capture curiosity } \\
\text { and discovery about learning, resilience, } \\
\text { attachment with parent, and contentment } \\
\text { with life. The survey question asked, } \\
\text { "How true are each of the following state- } \\
\text { ments about this child: (1) child is affec- } \\
\text { tionate and tender, (2) child bounces back } \\
\text { quickly when things don't go his/her way, } \\
\text { (3) child shows interest and curiosity in } \\
\text { learning new things, and (4) child smiles } \\
\text { and laughs a lot. The "Definitely true" } \\
\text { response to the question indicates the } \\
\text { child meets the flourishing item criteria. } \\
\text { Notes: Available for 1-2-year-olds. The } \\
\text { 2018 item cannot be combined with } 2017 \\
\text { due to changes in items between the } \\
\text { years. } 2018 \text { categories were: always, usu- } \\
\text { ally, sometimes, and never; whereas } 2017 \\
\text { categories were: definitely true, somewhat } \\
\text { true, and not true. Major redesign in } 2016 \text {, } \\
\text { including new sampling method. }\end{array}$ & $\begin{array}{l}\text { 2016-present } \\
\text { Annual }\end{array}$ \\
\hline $\begin{array}{l}\text { Social- } \\
\text { Emotional: } \\
\text { Bouncing } \\
\text { back }\end{array}$ & N/A & Infant/toddler & $\mathrm{NSCH}$ & $\begin{array}{l}\text { 2018: How often: Does this child bounce } \\
\text { back quickly when things do not go his or } \\
\text { her way? [Always; Usually; Sometimes; } \\
\text { Never] } \\
\text { 2016-2017: How well do each of the } \\
\text { following phrases describe (fill with } \\
\text { CHILD'S NAME)? (fill with CHILD'S } \\
\text { NAME) bounces back quickly when } \\
\text { things do not go his or her way? [Defi- } \\
\text { nitely true; Somewhat true; Not true] } \\
\text { Notes: Question is the same from } 2016 \text { to } \\
\text { 2018; however, the response options are } \\
\text { different in 2018. Major redesign in 2016, } \\
\text { including new sampling method. }\end{array}$ & $\begin{array}{c}\text { 2016-present } \\
\text { Annual }\end{array}$ \\
\hline $\begin{array}{l}\text { Social- } \\
\text { Emotional: } \\
\text { Smile/laugh }\end{array}$ & N/A & Infant/toddler & $\mathrm{NSCH}$ & $\begin{array}{l}\text { 2018: How often: Does this child smile and } \\
\text { laugh? [Always; Usually; Sometimes; } \\
\text { Never] } \\
\text { 2016-2017: How well do each of the } \\
\text { following phrases describe (fill with } \\
\text { CHILD'S NAME)? (fill with CHILD'S } \\
\text { NAME) smiles and laughs a lot. [Defi- } \\
\text { nitely true; Somewhat true; Not true] } \\
\text { Notes: Question is the same from } 2016 \text { to } \\
\text { 2018; however, the response options are } \\
\text { different in 2018. Major redesign in 2016, } \\
\text { including new sampling method. }\end{array}$ & $\begin{array}{l}\text { 2016-present } \\
\text { Annual }\end{array}$ \\
\hline
\end{tabular}




\begin{tabular}{|c|c|c|c|c|c|}
\hline Indicator & $\begin{array}{l}\text { Subdo- } \\
\text { main }\end{array}$ & $\begin{array}{l}\text { Developmen- } \\
\text { tal stage }\end{array}$ & $\begin{array}{l}\text { Data } \\
\text { source }\end{array}$ & Definition by data source and notes & $\begin{array}{l}\text { Years available } \\
\text { and periodicity }\end{array}$ \\
\hline $\begin{array}{l}\text { Social- } \\
\text { Emotional: } \\
\text { Affectionate/ } \\
\text { tender }\end{array}$ & N/A & Infant/toddler & $\mathrm{NSCH}$ & $\begin{array}{l}\text { 2018: How often: Is this child is affectionate } \\
\text { and tender with you? [Always; Usually; } \\
\text { Sometimes; Never] } \\
\text { 2017-2016: How well do each of the } \\
\text { following phrases describe (fill with } \\
\text { CHILD'S NAME)? (fill with CHILD'S } \\
\text { NAME) is affectionate and tender with } \\
\text { you. [Definitely true; Somewhat true; } \\
\text { Not true] } \\
\text { Notes: Question is the same from } 2016 \text { to } \\
\text { 2018; however, the response options are } \\
\text { different in 2018. Major redesign in 2016, } \\
\text { including new sampling method. }\end{array}$ & $\begin{array}{c}\text { 2016-present } \\
\text { Annnual }\end{array}$ \\
\hline $\begin{array}{l}\text { Social- } \\
\text { Emotional: } \\
\text { Curiosity }\end{array}$ & N/a & Infant/toddler & $\mathrm{NSCH}$ & $\begin{array}{l}\text { 2018: Header: How often: Does this child } \\
\text { show interest and curiosity in learning } \\
\text { new things? [Always; Usually; Some- } \\
\text { times; Never] } \\
\text { 2017-2016: Header: How well do each of } \\
\text { the following phrases describe (fill with } \\
\text { CHILD'S NAME)? (fill with CHILD'S } \\
\text { NAME) shows interest and curiosity in } \\
\text { learning new things. [Definitely true; } \\
\text { Somewhat true; Not true] } \\
\text { Notes: Question is the same from } 2016 \text { to } \\
\text { 2018; however, the response options are } \\
\text { different in 2018. Major redesign in 2016, } \\
\text { including new sampling method. }\end{array}$ & $\begin{array}{l}\text { 2016-present } \\
\text { Annual }\end{array}$ \\
\hline \multicolumn{6}{|c|}{ Family/caregiver indicators $^{\mathrm{a}}$} \\
\hline $\begin{array}{l}\text { Adverse } \\
\text { childhood } \\
\text { experiences } \\
\text { (ACEs): } \\
\text { Child expo- } \\
\text { sure }\end{array}$ & N/A & Infant/toddler & $\mathrm{NSCH}$ & $\begin{array}{l}\text { Number of ACEs experienced by infants/ } \\
\text { toddlers. The ACEs included in the } \\
\text { NSCH include: economic hardship, } \\
\text { parent/guardian separated or divorced, } \\
\text { parent/guardian died, parent/guardian } \\
\text { incarcerated, witness of abuse, witness or } \\
\text { victim of neighborhood violence, living } \\
\text { with someone with mental health chal- } \\
\text { lenges, living with someone with alcohol/ } \\
\text { drug abuse, and being treated with bias } \\
\text { due to race or ethnicity. } \\
\text { Notes: Major redesign in 2016, including } \\
\text { new sampling method. }\end{array}$ & $\begin{array}{l}\text { 2016-present } \\
\text { Annual }\end{array}$ \\
\hline
\end{tabular}




\begin{tabular}{|c|c|c|c|c|c|}
\hline Indicator & $\begin{array}{l}\text { Subdo- } \\
\text { main }\end{array}$ & $\begin{array}{l}\text { Developmen- } \\
\text { tal stage }\end{array}$ & $\begin{array}{l}\text { Data } \\
\text { source }\end{array}$ & Definition by data source and notes & $\begin{array}{l}\text { Years available } \\
\text { and periodicity }\end{array}$ \\
\hline $\begin{array}{l}\text { ACEs: } \\
\text { Economic } \\
\text { hardship }\end{array}$ & N/A & Infant/toddler & $\mathrm{NSCH}$ & $\begin{array}{l}\text { 2018: SINCE THIS CHILD WAS BORN, } \\
\text { how often has it been very hard to cover } \\
\text { the basics, like food and housing, on } \\
\text { your family's income? [Never; Rarely; } \\
\text { Somewhat often; Very often] } \\
\text { 2016-17: SINCE THIS CHILD WAS } \\
\text { BORN, how often has it been very hard } \\
\text { to get by on your family's income - hard } \\
\text { to cover the basics like food or housing? } \\
\text { [Never; Rarely; Somewhat often; Very } \\
\text { often] } \\
\text { Notes: Major redesign in 2016, including } \\
\text { new sampling method. The wording of } \\
\text { this individual item changed with } 2018 \\
\text { and is not comparable across years; } \\
\text { however, the overall ACE score can still } \\
\text { be compared. }\end{array}$ & $\begin{array}{c}\text { 2016-present } \\
\text { Annual }\end{array}$ \\
\hline $\begin{array}{l}\text { ACEs: Parent/ } \\
\text { guardian } \\
\text { separated or } \\
\text { divorced }\end{array}$ & N/A & Infant/toddler & $\mathrm{NSCH}$ & $\begin{array}{l}\text { To the best of your knowledge, has this } \\
\text { child EVER experienced any of the fol- } \\
\text { lowing? Parent or guardian divorced or } \\
\text { separated [Yes; No] } \\
\text { Notes: Major redesign in 2016, including } \\
\text { new sampling method. }\end{array}$ & $\begin{array}{c}\text { 2016-present } \\
\text { Annual }\end{array}$ \\
\hline $\begin{array}{l}\text { ACEs: Parent/ } \\
\text { guardian } \\
\text { died }\end{array}$ & N/A & Infant/toddler & $\mathrm{NSCH}$ & $\begin{array}{l}\text { To the best of your knowledge, has this } \\
\text { child EVER experienced any of the fol- } \\
\text { lowing? Parent or guardian died [Yes; No] } \\
\text { Notes: Major redesign in 2016, including } \\
\text { new sampling method. }\end{array}$ & $\begin{array}{c}\text { 2016-present } \\
\text { Annual }\end{array}$ \\
\hline $\begin{array}{l}\text { ACEs: Parent/ } \\
\text { guardian } \\
\text { incarcerated }\end{array}$ & N/A & Infant/toddler & $\mathrm{NSCH}$ & $\begin{array}{l}\text { To the best of your knowledge, has this } \\
\text { child EVER experienced any of the fol- } \\
\text { lowing? Parent or guardian served time in } \\
\text { jail [Yes; No] } \\
\text { Notes: Major redesign in 2016, including } \\
\text { new sampling method. }\end{array}$ & $\begin{array}{c}\text { 2016-present } \\
\text { Annual }\end{array}$ \\
\hline $\begin{array}{l}\text { ACEs: } \\
\text { Witnessed } \\
\text { abuse }\end{array}$ & N/A & Infant/toddler & $\mathrm{NSCH}$ & $\begin{array}{l}\text { To the best of your knowledge, has this } \\
\text { child EVER experienced any of the fol- } \\
\text { lowing? Saw or heard parents or adults } \\
\text { slap, hit, kick, punch one another in the } \\
\text { home [Yes; No] } \\
\text { Notes: Major redesign in 2016, including } \\
\text { new sampling method. }\end{array}$ & $\begin{array}{c}\text { 2016-present } \\
\text { Annual }\end{array}$ \\
\hline $\begin{array}{l}\text { ACEs: Witness } \\
\text { or victim or } \\
\text { neighbor- } \\
\text { hood } \\
\text { violence }\end{array}$ & N/A & Infant/toddler & $\mathrm{NSCH}$ & $\begin{array}{l}\text { To the best of your knowledge, has this } \\
\text { child EVER experienced any of the } \\
\text { following? Was a victim of violence or } \\
\text { witnessed violence in his or her neighbor- } \\
\text { hood [Yes; No] } \\
\text { Notes: Major redesign in 2016, including } \\
\text { new sampling method. }\end{array}$ & $\begin{array}{c}\text { 2016-present } \\
\text { Annual }\end{array}$ \\
\hline
\end{tabular}




\begin{tabular}{|c|c|c|c|c|c|}
\hline Indicator & $\begin{array}{l}\text { Subdo- } \\
\text { main }\end{array}$ & $\begin{array}{l}\text { Developmen- } \\
\text { tal stage }\end{array}$ & $\begin{array}{l}\text { Data } \\
\text { source }\end{array}$ & Definition by data source and notes & $\begin{array}{l}\text { Years available } \\
\text { and periodicity }\end{array}$ \\
\hline $\begin{array}{l}\text { ACEs: Lived } \\
\text { with } \\
\text { someone } \\
\text { with mental } \\
\text { health }\end{array}$ & N/A & Infant/toddler & $\mathrm{NSCH}$ & $\begin{array}{l}\text { To the best of your knowledge, has this } \\
\text { child EVER experienced any of the } \\
\text { following? Lived with anyone who } \\
\text { was mentally ill, suicidal, or severely } \\
\text { depressed [Yes; No] } \\
\text { Notes: Major redesign in 2016, including } \\
\text { new sampling method. }\end{array}$ & $\begin{array}{l}\text { 2016-present } \\
\text { Annual }\end{array}$ \\
\hline $\begin{array}{l}\text { ACEs: Lived } \\
\text { with some- } \\
\text { one with } \\
\text { alcohol/drug } \\
\text { abuse }\end{array}$ & N/A & Infant/toddler & $\mathrm{NSCH}$ & $\begin{array}{l}\text { To the best of your knowledge, has this } \\
\text { child EVER experienced any of the } \\
\text { following? Lived with anyone who had a } \\
\text { problem with alcohol or drugs [Yes; No] } \\
\text { Notes: Major redesign in 2016, including } \\
\text { new sampling method. }\end{array}$ & $\begin{array}{l}\text { 2016-present } \\
\text { Annual }\end{array}$ \\
\hline $\begin{array}{c}\text { ACEs: Treated } \\
\text { with racial/ } \\
\text { ethnic bias }\end{array}$ & N/A & Infant/toddler & $\mathrm{NSCH}$ & $\begin{array}{l}\text { To the best of your knowledge, has this child } \\
\text { EVER experienced any of the following? } \\
\text { Treated or judged unfairly because of his } \\
\text { or her race or ethnic group [Yes; No] } \\
\text { Notes: Major redesign in 2016, including } \\
\text { new sampling method. }\end{array}$ & $\begin{array}{c}\text { 2016-present } \\
\text { Annual }\end{array}$ \\
\hline $\begin{array}{l}\text { Shared family } \\
\text { meals }\end{array}$ & N/A & Infant/toddler & $\mathrm{NSCH}$ & $\begin{array}{l}\text { During the past week, on how many days } \\
\text { did all the family members who live in the } \\
\text { household eat a meal together? [0 days; } \\
1-3 \text { days; 4-6 days; Every day] } \\
\text { Notes: Major redesign in 2016, including } \\
\text { new sampling method. }\end{array}$ & $\begin{array}{l}\text { 2016-present } \\
\text { Annual }\end{array}$ \\
\hline $\begin{array}{l}\text { Family resil- } \\
\text { ience }\end{array}$ & N/A & Infant/toddler & $\mathrm{NSCH}$ & $\begin{array}{l}\text { When your family faces problems, how often } \\
\text { are you likely to do each of the following? } \\
\text { (a) talk together about what to do, (b) } \\
\text { work together to solve our problems, (c) } \\
\text { know we have strengths to draw on, and } \\
\text { (d) stay hopeful even in difficult times. } \\
\text { [Children who live in a family that met } \\
0-1 \text { family resilience items; Children who } \\
\text { live in a family that met } 2-3 \text { family resil- } \\
\text { ience items; Children who live in a family } \\
\text { that met all } 4 \text { family resilience items] } \\
\text { Notes: Major redesign in 2016, including } \\
\text { new sampling method }\end{array}$ & $\begin{array}{l}\text { 2016-present } \\
\text { Annual }\end{array}$ \\
\hline $\begin{array}{l}\text { Parental aggra- } \\
\text { vation }\end{array}$ & N/A & Infant/toddler & $\mathrm{NSCH}$ & $\begin{array}{l}\text { Whether or not child lived with parents who } \\
\text { often feel aggravation from parenting } \\
\text { based on the following three items: } \\
\text { During the past month, how often have } \\
\text { you felt: } \\
\text { - That this child is much harder to care for } \\
\text { than most children his or her age? [Never; } \\
\text { Rarely; Sometimes; Usually; Always] } \\
\text { - That this child does things that really } \\
\text { bother you a lot? [Never; Rarely; Some- } \\
\text { times; Usually; Always] } \\
\text { - Angry with this child? [Never; Rarely; } \\
\text { Sometimes; Usually; Always] } \\
\text { Notes: Major redesign in 2016, including } \\
\text { new sampling method. }\end{array}$ & $\begin{array}{l}\text { 2016-present } \\
\text { Annual }\end{array}$ \\
\hline
\end{tabular}




\begin{tabular}{|c|c|c|c|c|c|}
\hline Indicator & $\begin{array}{l}\text { Subdo- } \\
\text { main }\end{array}$ & $\begin{array}{l}\text { Developmen- } \\
\text { tal stage }\end{array}$ & $\begin{array}{l}\text { Data } \\
\text { source }\end{array}$ & Definition by data source and notes & $\begin{array}{l}\text { Years available } \\
\text { and periodicity }\end{array}$ \\
\hline $\begin{array}{l}\text { Father on birth } \\
\text { certificate }\end{array}$ & $\mathrm{N} / \mathrm{A}$ & Infant & $\begin{array}{l}\text { NVSS } \\
\text { birth } \\
\text { cer- } \\
\text { tificate } \\
\text { files }^{\text {b }}\end{array}$ & $\begin{array}{l}\text { Parents married or paternal acknowledge- } \\
\text { ment } \\
\text { Notes: Prior to 2016, CDC WONDER only } \\
\text { has data on mother's marital status. From } \\
2016 \text { to } 2018 \text {, paternal acknowledgement } \\
\text { is also included. Beginning in } 2017 \text {, due } \\
\text { to state statutory restrictions, California } \\
\text { no longer provides record-level data on } \\
\text { paternity acknowledgment for births } \\
\text { occurring to California residents and } \\
\text { non-residents (including residents of } \\
\text { other states). For these births, Paternity } \\
\text { Acknowledgment is reported as "Not } \\
\text { Reported." }\end{array}$ & $\begin{array}{l}\text { 2016-present } \\
\text { Annual }\end{array}$ \\
\hline
\end{tabular}

${ }^{\mathrm{a}}$ Many of the family/caregiver indicators are related to multiple domains. To streamline this manuscript, we placed the indicators in the most aligned domain

${ }^{\mathrm{b}}$ Vital statistics data were accessed through CDC Wonder (wonder.cdc.gov). Additional data, including more historical data, may be available through the National Center for Health Statistics' Vital Statistics Online Data Portal (https://www.cdc.gov/nchs/data_access/vitalstatsonline.htm)

Acknowledgements We are grateful to the reviewers that supported this work by serving on our two expert panels, as well as the following Measuring Up Collaborative members for their support of and feedback on the project: Kimberly Ross, Coleen Boyle, Georgina Peacock, Lara Robinson, Julia Abercrombie, and Dina Lieser. The Measuring Up Collaborative is a collaboration between developmental psychologists, sociologists, and public health experts from Child Trends, the Centers for Disease Control and Prevention (CDC), the Georgia Department of Public Health (GA-DPH), the U.S. Health Resources and Services Administration (HRSA), and the Marcus Autism Center (MAC). Additionally, we would like to acknowledge the research support from Fadumo Abdi, Kristen Darling, Dayne Ornelas Gonzalez, Jessie Laurore, and Ambika Mathur.

\section{Declarations}

Funding This was work was supported by grants from the Jesse Parker Williams Foundation (Atlanta), the Marcus Autism Center, and the J. B. Whitehead Foundation (Atlanta), and the Georgia Department of Public Health.

\section{Conflicts of interest/Competing interests None to report.}

Availability of data and material Not applicable.

Code availability Not applicable.

Open Access This article is licensed under a Creative Commons Attribution 4.0 International License, which permits use, sharing, adaptation, distribution and reproduction in any medium or format, as long as you give appropriate credit to the original author(s) and the source, provide a link to the Creative Commons licence, and indicate if changes were made. The images or other third party material in this article are included in the article's Creative Commons licence, unless indicated otherwise in a credit line to the material. If material is not included in the article's Creative Commons licence and your intended use is not permitted by statutory regulation or exceeds the permitted use, you will need to obtain permission directly from the copyright holder. To view a copy of this licence, visit http://creativecommons.org/licen ses/by/4.0/. 


\section{References}

Bailey, M. J., Timpe, B., \& Sun, S. (2020). Prep school for poor kids: The long-run impacts of head start on human capital and economic self-sufficiency (NBER Working Paper No. w28268). https://www. nber.org/papers/w28268

Ben-Arieh, A., Kaufman, H. N., Andrews, B. A., Goerge, R., Lee, B.J., \& Aber, J.L. (2001). Measuring and monitoring children's well-being. Kluwer Academic Press.

Black, M. M., Walker, S. P., Fernald, L. C. H., Andersen, C. T., DiGirolamo, A. M., Lu, C., McCoy, D. C., Fink, G., Shawar, Y. R., Shiffman, J., Devercelli, A. E., Wodon, Q. T., Vargas-Barón, E., Granthan-McGregor, S., \& Lancet Early Childhood Development Series Steering Committee. (2017). Early childhood development coming of age: Science through the life course. Lancet, 389(10064), 77-90. https://doi.org/10.1016/S0140-6736(16)31389-7

Black, M., Bromley, K., Cavallera, V., Cuartas, J., Dua, T., Eekhout, I., Fik, G., Gladstone, M., Hepworth, K., Janus, M., Kariger, P., Lancaster, G., McCoy, D., McCray, G., Raikes, A., Rubio-Codina, M., van Buuren, S., Waldman, M., Walker, S., \& Weber, A. (2019). The Global Scale for Early Development (GSED). Early Childhood Matters. https://earlychildhoodmatters.onlaine/2019/the-globalscale-for-early-development-gsed/?ecm2019

Brito, N. H., Fifer, W. P., Amso, D., Barr, R., Bell, M. A., Calkins, S., Flynn, A., Montgomery-Downs, H. E., Oakes, L. M., Richards, J. E., Samuelson, L. M., \& Colombo, J. (2019). Beyond the Bayley: Neurocognitive assessments of development during infancy and toddlerhood. Developmental Neuropsychology, 44(2), 220-247. https://doi.org/10.1080/87565641.2018.1564310

Bronfenbrenner, U. (1979). The ecology of human development: Experiments by nature and design. Harvard University Press.

Bronfenbrenner, U. (1992). Ecological systems theory. In R. Vasta (Ed.), Six theories of child development: Revised formulations and current issues (pp. 187-249). Jessica Kingsley Publishers.

Bronfenbrenner, U. \& Morris, P. (2007). The bioecological model of human development. In R. Lerner (Ed.), Handbook of child psychology (pp. 795-825). Wiley.

*Centers for Disease Control and Prevention. (n.d.). CDC Wonder. http://wonder.cdc.gov/.

*Centers for Disease Control and Prevention, National Center for Immunization and Respiratory Diseases. (2020). National Immunization Survey-Child. A codebook for the 2018 public-use data file [Codebook]. https://www.cdc.gov/vaccines/imz-managers/nis/downloads/NIS-PUF18-CODEBOOK.pdf

Center on the Developing Child. (2007). Early childhood program effectiveness (InBrief). https://developingchild.harvard.edu/resources/inbrief-early-childhood-program-effectiveness/

Center on the Developing Child (2010). The foundations of lifelong health are built in early childhood. https://developingchild.harvard.edu/resources/the-foundations-of-lifelong-health-are-built-in-early -childhood/

Centers for Disease Control and Prevention. (2021). Infant mortality rates by state. https://www.cdc.gov/ nchs/pressroom/sosmap/infant_mortality_rates/infant_mortality.htm

Centers for Disease Control and Prevention. National Center for Chronic Disease Prevention and Health Promotion, Division of Nutrition, Physical Activity, and Obesity. (2021). Data, trend and maps [online]. https://www.cdc.gov/nccdphp/dnpao/data-trends-maps/index.html

*Child and Adolescent Health Measurement Initiative. (2018). 2016 National Survey of Children's Health: Child and family health measures and subgroups [SPSS Codebook, Version 2.0]. Data Resource Center for Child and Adolescent Health supported by the U.S. Department of Health and Human Services, Health Resources and Services Administration (HRSA), Maternal and Child Health Bureau (MCHB). www.childhealthdata.org.

*Child and Adolescent Health Measurement Initiative. (2019a). 2016-2017 National Survey of Children's Health (2 years combined data set): Child and family health measures, national performance and outcome measures, and subgroups [SAS Data Set, Version 1.0]. Data Resource Center for Child and Adolescent Health supported by Cooperative Agreement U59MC27866 from the U.S. Department of Health and Human Services, Health Resources and Services Administration (HRSA), Maternal and Child Health Bureau (MCHB). www.childhealthdata.org

*Child and Adolescent Health Measurement Initiative. (2019b). 2017-2018 National Survey of Children's Health (2 years combined data set) [Stata Data Set]. Data Resource Center for Child and Adolescent Health supported by Cooperative Agreement U59MC27866 from the U.S. Department of Health and Human Services, Health Resources and Services Administration (HRSA), Maternal and Child Health Bureau (MCHB). www.childhealthdata.org 
*Children's Bureau. (2019). National Child Abuse and Neglect Data System (NCANDS) child file codebook. Administration on Children, Youth and Families, Administration for Children and Families. U.S. Department of Health and Human Services. https://www.acf.hhs.gov/sites/default/files/documents/cb/ncands_child_file_codebook.pdf

Child Trends. (2020). Child Trends DataBank. https://childtrends.org/indicators?a-z

Coleman-Jensen, A., McFall, W., \& Nord, M. (2013). Food insecurity in households with children: Prevalence, severity, and household characteristics, 2010-11. U.S. Department of Agriculture, Economic Research Service. https://www.ers.usda.gov/webdocs/publications/43763/37672_eib-113. pdf? $\mathrm{v}=3041.5$

Exec. Order No. 13985, 86 Fed. Reg. 7009 (Jan. 20, 2021).

*Flood, S., King, M., Rodgers, R., Ruggles, S., \& Warren, J. R. (2020). Integrated Public Use Microdata Series, Current Population Survey: Version 8.9 [dataset].IPUMS. https://doi.org/10.18128/D030. V8.0

Halle, T. G. \& Moore, K. (1998). Creating indicators of positive development. In The Carter Center (Eds.), Promoting positive and healthy behaviors in children (pp. 59-65). The Carter Center.

Halle, T., Forry, N., Hair, E., Perper, K., Wandner, L., Wessel, J., \& Vick, J. (2009). Disparities in early learning and development: Lessons from the Early Childhood Longitudinal Study-Birth Cohort (ECLS-B). Child Trends. https://www.childtrends.org/publications/disparities-in-early-learning-anddevelopment-lessons-from-the-early-childhood-longitudinal-study-birth-cohort-ecls-b

Jordan, E., King, C., Banghart, P., \& Nugent, C. (2018). Improving the lives of young children through data. Early Childhood Data Collaborative. https://www.childtrends.org/publications/ improving-the-lives-of-young-children-through-data

Keating, K., Cole, P., \& Schaffner, M. (2020). State of babies yearbook 2020. Zero to Three. https://stateofbabies.org/wp-content/uploads/2020/06/State-of-Babies-2020-Full-Yearbook-061820.pdf

Lin, V-K. (2019). Identifying home visiting data to integrate with other early childhood data. Early Childhood Data Collaborative. https://www.childtrends.org/wp-content/uploads/2019/10/SHINE-brief-3_ ChildTrends_Oct2019.pdf

Lippman, L. (2007). Indicators and indices of child well-being: A brief American history. Social Indicators Research, 83, 39-53. https://doi.org/10.1007/s11205-006-9058-2

Lippman, L. H., Moore, K. A., Guzman, L., Ryberg, R., McIntosh, H., Ramos, M., Caal, S., Carle, A., \& Kuhfeld, M. (2014). Flourishing children: Defining and testing indicators of positive development. Springer.

Masten, A. S., \& Cicchetti, D. (2010). Developmental cascades. Developmental Psychopathology, 22(3), 491-495. https://doi.org/10.1017/S0954579410000222

Moore, K. A. (2020). Developing an indicators system to measure child well-being: Lessons learned over time. Child Indicators Research, 13, 727-739. https://doi.org/10.1007/s12187-019-09644-4

Moore, K. A., \& Brown, B. V. (2003). The uses (and misuses) of social indicators: Implications for public policy. Child Trends. https://www.childtrends.org/wp-content/uploads/2003/02/child_trends2003_02_01_rb_useandmisuse.pdf

Moore, K. A., \& Halle, T. G. (2001). Preventing problems vs. promoting the positive: What do we want for our children? In S. Hofferth \& T. Owens (Eds.), Children at the millennium: Where have we come from, where are we going? (pp. 141-170). JAI Press.

Moore, K. A., Lippman, L., \& Brown, B. (2004). Indicators of child well-being: The promise for positive youth development. Annals of the American Academy of Political and Social Science, 591(1), 125-145. https://doi.org/10.1177/0002716203260103

National Center for Children in Poverty. (2018). Early childhood profiles. National Center for Children in Poverty. Bank Street Graduate School of Education. http://stage.nccp.org/profiles/early_childhood.html

National Research Council; Institute of Medicine. (2004). Children's health, the nation's wealth: Assessing and improving child health. National Academies Press. https://doi.org/10.17226/10886

Northam, S., \& Knapp, T. (2006). The reliability and validity of birth certificates. Journal of Obstetric, Gynecologic \& Neonatal Nursing, 35(1), 3-12. https://doi.org/10.1111/j.1552-6909.2006.00016.x

Oreopoulos, P., Stabile, M., Walld, R., \& Roos, L. L. (2008). Short-, medium-, and long-term consequences of poor infant health: An analysis using siblings and twins. Journal of Human Resources, 43(1), 88-138. https://doi.org/10.3368/jhr.43.1.88

Paschall, K., Moore, K. A., Piña, G., \& Anderson, S. (2020). Comparing the national outcome measure of healthy and ready to learn with other well-being and school readiness measures. Child Trends. https:// www.childtrends.org/publications/comparing-the-national-outcome-measure-of-healthy-and-ready-tolearn-with-other-well-being-and-school-readiness-measures 
Piña, G., Moore, K. A., Paschall, K., \& Anderson, S. (2020). Being healthy and ready to learn is linked with socioeconomic conditions for preschoolers. Child Trends. https://www.childtrends.org/publications/ being-healthy-and-ready-to-learn-is-linked-with-socioeconomic-conditions-for-preschoolers

Prenatal-to-3 Policy Impact Center. (2020). Prenatal-to-3 state policy roadmap 2020: Building a strong and equitable prenatal-to-3 system of care. Child and Family Research Partnership. Lyndon B. Johnson School of Public Affairs, University of Texas at Austin. http://pn3policy.org/pn-3-statepolicy-roadmap

Prenatal-to-3 Policy Impact Center. (2021). Why do we focus on the prenatal-to-3 age period? Understanding the importance of the earliest years (B.001.0121). Child and Family Research Partnership, Lyndon B. Johnson School of Public Affairs, University of Texas at Austin. https://pn3policy.org/ resources/why-do-we-focus-on-the-prenatal-to-3-age-period-understanding-the-importance-of-theearliest-years

Raikes, A., Yoshikawa, H., Britto, P. R., \& Iruka, I. (2017). Children, youth and developmental science in the 2015-2013 global Sustainable Development Goals. Social Policy Report, 30(3). https://doi.org/ 10.1002/j.2379-3988.2017.tb00088.x

*Ruggles, S., Flood, S., Goeken, R., Grover, J., Meyer, E., Pacas, J., Sobek, M. (2020). IPUS USA: Version 10.0 [Dataset]. IPUMS, 2020. https://doi.org/10.18128/D010.V10.0

Salemi, J. L., Tanner, J. P., Sampat, D. P., Rutkowski, R. E., Anjohrin, S. B., Marshall, J., \& Kirby, R. S. (2017). Evaluation of the sensitivity and accuracy of birth defects indicators on the 2003 revision of the U.S. birth certificate: Has data quality improved? Paediatric and Perinatal Epidemiology, 31(1), 67-75. https://doi.org/10.1111/ppe.12326

Shonkoff, J. P., \& Phillips, D. A. (2000). From neurons to neighborhoods: The science of early childhood development. National Academy Press.

Szilagyi, P. G., \& Schor, E. L. (1998). The health of children. Health Services Research, 33(4 Pt 2), 1001-1039.

The Alliance for Child Protection in Humanitarian Action. (2021). Defining and measuring child well-being in humanitarian action: A contextualization guide. https://www.alliancecpha.org/ en/system/tdf/library/attachments/cpha002_-_child_well-being_contextualisation_guide_v6_1. pdf?file $=1 \&$ type $=$ node $\&$ id $=42528$

United States Census Bureau. (2021b). State oversampling in the National Survey of Children's Health: Feasibility, cost, and FAQs. Census Bureau. https:/www.census.gov/content/dam/Census/progr ams-surveys/nsch/NSCH_State_Oversample_Summary_Document.pdf

United States Census Bureau, Associate Director of Demographic Programs, National Survey of Children's Health. (2021a). National survey of children's health frequently asked questions. https:// www2.census.gov/programs-surveys/nsch/technical-documentation/methodology/2020-NSCHFAQs.pdf

*United States Department of Health and Human Services (US DHHS), Centers for Disease Control and Prevention (CDC). (2019). Behavioral Risk Factor Surveillance System survey questionnaire. [Questionnaire]. https://www.cdc.gov/brfss/questionnaires/index.htm

Wilkinson, A., Laurore, J., Maxfield, E., Gross, E., Daily, S., \& Keating, K. (2021). Racism creates inequities in maternal and child health, even before birth. Child Trends. https://www.childtrends.org/ publications/racism-creates-inequities-maternal-child-health-even-before-birth

World Health Organization, United Nations Children's Fund, World Bank Group. (2018). Nurturing care for early childhood development: A framework for helping children survive and thrive to transform health and human potential. World Health Organization. https://apps.who.int/iris/bitstream/han dle/10665/272603/9789241514064-eng.pdf

Publisher's note Springer Nature remains neutral with regard to jurisdictional claims in published maps and institutional affiliations. 